\title{
War and Peace- An Israeli Perspective
}

\section{Asher Maoz*}

\section{INTRODUCTION}

The State of Israel was born in the storm of war and has been in a state of military confrontation ever since, which continues even as these lines are being written. Israel has fought six full-scale wars since its establishment: the War of Independence (1948), the Sinai War (1956), the Six Day War (1967), the War of Attrition (1970s), the Yom Kippur - or October - War (1973), and the Lebanon War (1982). Furthermore, the periods between the wars were not without military unrest. Israel has found itself in unabated military confrontations, most recently capped by the uprising (known in Arabic as the Intifada) being waged against it by the Palestinian Authority since September 2000.

It is thus surprising that until the latter half of the 1990s, Israeli law had no statutory arrangement governing the rules of military confrontation, and specifically for starting a war. This is partly because, even today, Israel has no comprehensive written constitution. The Declaration of the Establishment of the State of Israel, of 14 May $1948^{1}$ determined that a constituent assembly would be elected, and would

I wish to thank Justice Elyakim Rubinstein, from the Supreme Court of the State of Israel and former attorney general of the State of Israel, who read a former draft of the article and made valuable suggestions. I also express my gratitude to Alan Baker, Israel's ambassador to Canada and former legal advisor of the Ministry of Foreign Affairs and to Colonel (Res.) Daniel Reisner, former head of the International Law Branch of the Israel Defence Forces, Legal Division, who supplied me with relevant materials and information. Advocate Michael Sfard, who represents the petitioners in H.C.J. 769/02, supplied me with the briefs that he submitted in that case.

Laws of the State of Israel 5708/1948, vol. 1, 3 [Official English Translation of Israeli Statutes] [L.S.I ] (reproduced in John N. Moore, The Arab-Israeli Conflict (Princeton: Princeton University Press, 1974) vol. 3 at 348, and in Ruth Lapidoth \& Moshe Hirsch, The Arab-Israel Conflict and its Resolution: Selected Documents (Dordrecht: Martinus Nijhoff Publishers, 1992) at 61). provide the state with a constitution no later than 1 October 1948. The constituent assembly was elected and served simultaneously as a constituent assembly and a parliament, giving itself the name "Knesset." However, the constituent assembly did not give the state a constitution. Instead, it charged its Constitution, Law and Justice Committee with the task of drafting a constitution comprising a number of Basic Laws, which would be submitted for Knesset approval and subsequently consolidated into the state constitution. ${ }^{3}$ It was only in 1968 that the Knesset adopted the Basic Law: The Government. ${ }^{4}$ However, even this Basic Law was silent regarding the power to declare war. The power to declare war was statutorily entrenched for the first time in 1992 with the adoption of the

Asher Maoz, "Defending Civil Liberties Without a Constitution - The Israeli Experience" (1988) 16 Melbourne University Law Review 815 at 818 . The term "Knesset" is the Hebrew equivalent of "Assembly" and was adopted from the central institution that governed the Jewish State during the Second Commonwealth, "Knesset Gedola," meaning "The Great Assembly." See Report of the Minister of Justice in Divrei HaKnesset (Parliamentary Debates) [D.K.] 1949, vol. 1, 15 (Hebrew). See also, Israel Government Year Book 1968-1969 (Jerusalem: Government Printer for Central Office, 1969) at 21. For the role of the Great Assembly, see Salo Baron, A Social and Religious History of the Jews, $2 \mathrm{~d}$ ed. (New York: Columbia University Press, 1952) vol. 1 at 368 .

D.K. 1950, vol. 5, 1743. For a description of the evolution of the constitutive authority, see Asher Maoz, "Constitutional Law" in Itzhak Zamir \& Sylviance Colombo, eds., The Law of Israel: General Surveys (Jerusalem: Hebrew University of Jerusalem, 1995) 6 at 6-13; David Kretzmer, "Constitutional Law" in Amos Shapira \& Keren DeWitt-Arar, eds., Introduction to the Law of Israel (The Hague: Kluwer Law International, 1995) 39 at 45-55; Daphne Barak-Erez, "From an Unwritten to a Written Constitution: The Israeli Challenge in American Perspective" (1995) 26 Columbia Human Rights Law Review 309; Marcia Gelpe, "Constraints on Supreme Court Authority in Israel and the United States: Phenomenal Cosmic Powers; Itty Bitty Living Space" (1999) 13 Emory International Law Review 493 at 495, 500-505.

4 L.S.I. 5728/1968, vol. 22, 257 [Basic Law: The Government (1968)]. 
revised Basic Law: The Government..$^{5}$ This law came into effect in 1996, five decades after the establishment of the state. Moreover, to this very day, the legal situation is not clear and unequivocal. ${ }^{6}$

This article begins with a discussion of the legal status of the relations between Israel and the various Arab countries from the perspective of the laws of war. It will then discuss the power and procedure for a declaration of war in Israel. Finally, it will discuss the legal status of an "armed conflict short of war," in which the State of Israel is currently involved.

\section{THE LEGAL STATUS OF THE RELATIONS BETWEEN ISRAEL AND THE ARAB STATES}

On 29 November 1947, the General Assembly of the United Nations adopted UN General Assembly Resolution 181 (II), concerning the Future Government of Palestine, known as the "Partition Plan."

The resolution called for the termination of the British Mandate over Palestine and the establishment of two independent states - one Arab and the other Jewish. It further provided that Jerusalem would be controlled by a Special International Regime to be established in the area evacuated by the Mandate forces. The Jewish Agency for Palestine, on behalf of the Jewish Community in Palestine, accepted the resolution. ${ }^{8}$ On the other hand, the Arab Higher Committee, on behalf of the Palestinian Arabs, rejected it in a statement made to the Ad Hoc Committee on the

Sefer Ha-Hukim (Book of Laws) [S.H.] 5752/1992-1993, 214 (Hebrew) [Basic Law: The Government (1992)]. There is no official translation of this Basic Law. A non-binding translation appears online: Knesset, The Basic Laws: Full Texts $<$ http://www.knesset.gov.il/laws/special/eng/basic7 eng.htm>. No less surprising is the dearth of discussion regarding the legal aspects of the relationship between the political level and the military level. See Eyal Nun, "The Constitutional Restrictions upon the Army in Israel" (1999-2000) 16 Israel Defence Forces Law Review 79 at 79-82 (Hebrew).

UN GAOR, 2d Sess., UN Doc. A/519 (1948) (reproduced in Moore, supra note 1 at 313 , and in Lapidoth \& Hirsch, supra note 1 at 33 ).

Ad Hoc Committee on Palestine, UN GAOR, 2d Sess., 4th Mtg., UN Doc. GA/PAL/4 (1947) at 12-19 (reproduced in Lapidoth \& Hirsch, ibid. at 55).
Palestinian Question. ${ }^{9}$ Following the rejection, representatives of Saudi Arabia, ${ }^{10}$ Pakistan, ${ }^{11}$ Iraq, ${ }^{12}$ Syria, ${ }^{13}$ and Yemen ${ }^{14}$ made statements at the plenary meeting of the General Assembly fulminating against the decision. The United Nations' resolution led to the outbreak of hostilities in Palestine, as a result of the Arabs' attempt to frustrate the realization of the resolution. The Palestinian Arabs took part in the struggle together with irregular volunteer forces sent by the Arab states in accordance with the decision adopted by the Political Committee of the Arab League. At that time the League consisted of the following Arab states: Egypt, Syria, Lebanon, Iraq, Transjordan (Jordan), Saudi Arabia, and Yemen. These forces made up the Arab Liberation Army.

The British regime also attempted to forestall the UN Assembly's resolution. It unilaterally advanced its withdrawal date from Palestine to 15 May 1948 and did not cooperate with the UN Commission. The Commission was supposed to assume control over the territories vacated by the British, in order to ensure the establishment of provisional councils of government in the territories designated for the Arab state and the Jewish State. In anticipation of the withdrawal of the British forces from Palestine, the representatives of the Jewish community in Palestine and of the Zionist movement assembled in Tel Aviv on 14 May 1948. They declared "the establishment of a Jewish State in Palestine, to be known as the State of Israel." 15

Ibid. at 5-11 (reproduced in Lapidoth \& Hirsch, ibid. at 57).

10 Statement to the Plenary Meeting of the General Assembly by the Representative of Saudi Arabia, UN GAOR, 2d Sess., Verbatim Record (16 September -29 November 1947), Vol. II (13 November - 29 November) at 1425 (reproduced in Lapidoth \& Hirsch, ibid. at 58) [translated from Arabic].

11 Statement to the Plenary Meeting of the General Assembly by the Representative of Pakistan, ibid. at 1426 (reproduced in Lapidoth \& Hirsch, ibid. at 59).

12 Statement to the Plenary Meeting of the General Assembly by the Representative of Pakistan, ibid. at 1426-27 (reproduced in Lapidoth \& Hirsch, ibid. at 60).

13 Statement to the Plenary Meeting of the General Assembly by the Representative of Syria, ibid. at 1427 (reproduced in Lapidoth \& Hirsch, ibid. at 60).

14 Statement to the Plenary Meeting of the General Assembly by the Representative of Yemen, ibid. at 1427 (reproduced in Lapidoth \& Hirsch, ibid. at 60).

15 Declaration of the Establishment of the State of Israel, supra note 1 . The declaration was brought forward by one day, given that 15 May fell on the Sabbath. 
On the following day, the governments of the Arab League states issued a statement declaring that they "[had] found themselves compelled to intervene in Palestine solely in order to help its inhabitants restore peace and security and the rule of justice and law to their country." ${ }^{16}$ The governments of the Arab League states undertook that their intervention would cease once "a unitary Palestinian State" was established by "the lawful inhabitants of Palestine." ${ }^{17}$ Indeed, following the declaration of the governments of the Arab League states, the combined armies of Egypt, Iraq, Jordan, Syria, and Lebanon invaded Palestine with the intention of fighting the Israeli forces and thwarting the establishment of the Jewish State. ${ }^{18}$ The Arab armies also received the assistance of volunteer forces from Saudi Arabia, Libya and Yemen.

UN Secretary-General Trygve Lie, on the other hand, regarded the invasion of Palestine by the Arab states as "the first armed aggression the world has seen since the end of the [second world] war." 19 Israel adopted a similar approach. For example, in Diab v. A.G., the Supreme Court described the conflict as follows:

The Arab-Israel War was ... a war between sovereign States on both sides, in which the aggressors, the seven Arab States, sought to destroy all that the Jews had created and erase the State of Israel from the map. This was a "territorial" war, a war between States, and it makes no difference that the aggressor-invaders themselves did not recognise the political existence of the victim State. It was recognised immediately after its birth by

16 Cablegram from the Secretary-General of the League of Arab States to the Secretary-General of the United Nations, 15 May 1948, UN Doc. S/745, reprinted in UN SCOR, 3d year, Supp. (May 1948) at 83-8 [Cablegram of the League of Arab States] (reproduced in Moore, supra note 1 at 352, and in Meron Medzini, ed., Israel's Foreign Relations: Selected Documents, 1947-1974 (Jerusalem: Ministry of Foreign Affairs, 1976) vol. 1 at 135-138; online: Israel Ministry of Foreign Affairs $<$ http://www.mfa.gov.il/MFA/Foreign+Relations/Israels+For eign+Relations + since+1947/1947-1974/>. Telegrams in a similar spirit were also sent by the Egyptian foreign minister (UN Doc. S/743) and by the King of Jordan (UN Doc. S/748).

17 Cablegram of the League of Arab States, ibid.

18 See Cablegram from the Jewish Agencyfor Palestine, Reporting the Armed Invasion, 16 May 1948, UN Doc. S/746 (reproduced in Medzini, supra note 16).

19 In the Cause of Peace: Seven Years with the United Nations (New York: Macmillan, 1954) at 174. powerful States, great nations of the earth, and became a living and actual reality on the political stage of the world. We never admitted that the Arab States came to help the Arabs of Palestine, or that the object of their war was to establish an independent Palestinian State within its former Mandatory borders, under the hegemony of the local Arabs. That, indeed, was the invaders' argument and ground for quarrel, as put forward by their spokesmen before the United Nations and in other forums, but the truth was very different. ${ }^{20}$

The war ended with a series of armistice agreements, signed between the State of Israel and its neighboring countries. These agreements followed a decision by the UN Security Council, calling upon the parties to negotiate the establishment of an armistice. ${ }^{21}$ The resolution urged the parties directly involved in the conflict in Palestine "to seek agreement ... with a view to the immediate establishment of an armistice ... to facilitate the transition from the present truce to permanent peace in Palestine." 22 The Security Council's decision led to the signing of ceasefire agreements between Israel and its neighbors:

20 (1952), Cr. A. 44/52, 6 P.D. (Law Reports of the Supreme Court of Israel) 922 at 932 (Hebrew), 19 I.L.R. 550 at 553, cited to online: The State of Israel, Judicial Authority $<$ http://elyon1.court.gov.il/files_eng/52/440/000/z01/520004 40.z01.htm >. On the other hand, the District Court held that the disturbances that took place from the date of the adoption of the Partition Resolution by the General Assembly of the United Nations until the Declaration of the Establishment of the State of Israel "did not constitute war in the sense of international law." This was because "it was not a condition in which two or more States were fighting one another, or in which two or more regular armies were opposed to one another." Cr. A. (Jerusalem) Abramovitz v. A.G., 4 P.M. (Law Reports of the District Courts) 441 at 445 (Hebrew), (1952) 19 I.L.R. 554 [translated by author].

${ }^{21}$ The Palestine Question, SC Res. 62, UN SCOR, 3d Year, Supp., UN Doc. S/1080 (1948) (reproduced in Lapidoth \& Hirsch, supra note 1 at 70 ).

22 Ibid. 
Egypt, ${ }^{23}$ Lebanon, ${ }^{24}$ Jordan, ${ }^{25}$ and Syria. ${ }^{26}$ The preamble to these agreements declared that they were signed in response "to the Security Council resolution of 16 November $1948 \ldots$ as a further provisional measure under Article 40 of the Charter of the United Nations and in order to facilitate the transition from the present truce to permanent peace in Palestine." ${ }^{27}$ Article 1, moreover, provided that the agreements were signed " $[\mathrm{w}]$ ith a view to promoting the restoration of permanent peace in Palestine." ${ }^{28}$ The agreements concluded with the explicit declaration that "they shall remain in force until a peaceful settlement between the Parties is achieved." 29

Iraq replied to the UN's invitation to enter into armistice negotiations with Israel, declaring that "the terms of armistice which will be agreed upon by the Arab States neighbors of Palestine namely Egypt, Transjordan, Syria and Lebanon will be regarded as acceptable to my [the Iraqi] Government." ${ }^{30}$ Saudi Arabia responded to the same invitation by declaring that "the Saudi Arabian troops participating in the Palestine campaign do not constitute an independent front, and there is no reason why Saudi Arabian government should enter into any negotiations to conclude a new truce while the truce imposed in July is still effective." ${ }^{31}$ Saudi Arabia added that

23 Egyptian-Israeli General Armistice Agreement, 24 February 1949, 42 U.N.T.S. 251-270, No. 654 (reproduced in Moore, supra note 1 at 380, and in Lapidoth \& Hirsch, ibid. at 74).

24 Israeli-Lebanese General Armistice Agreement, $23 \mathrm{March}$ 1949, 42 U.N.T.S. 287-298, No. 65, (reproduced in Moore, ibid. at 390, and in Lapidoth \& Hirsch, ibid. at 82).

25 Hashemite Jordan Kingdom-Israel General Armistice Agreement, 3 April 1949, 42 U.N.T.S. 303-320, No. 656 (reproduced in Moore, ibid. at 397, and in Lapidoth \& Hirsch, ibid. at 87).

26 Israeli-Syrian General Armistice Agreement, 20 July 1949, U.N.T.S. 327-340, No. 657 (reproduced in Moore, ibid. at 407, and in Lapidoth \& Hirsch, ibid. at 94).

27 Supra notes 23-26.

28 Ibid.

29 Ibid.

30 Cablegram from the Mediator to the Secretary-General Transmitting Replies of Arab States to Invitation for Armistice Negotiations, 24 February 1949, UN SCOR, UN Doc. S/1241 (1949) [Cablegram re Armistice Negotiations] in A Select Chronology and Background Documents Relating to the Middle East (Washington: U.S. G.P.O., 1967) at 56-57 (reproduced in Moore, supra note 1 at 377 , and in Lapidoth \& Hirsch, supra note 1 at 100$)$.

31 Cablegram re Armistice Negotiations, Ibid. Saudi Arabia was probably referring to the truce established through The Palestine Question, SC Res. 54, UN SCOR, 3d Year, Supp., UN Doc. S/902 (1948) at 76-77 (reproduced in Moore, ibid. at 362 , and in Lapidoth \& Hirsch, ibid. at 68). This resolution determined that the situation in Palestine constituted a threat to "[a]t any rate the Saudi Arabian government accepts the decisions which have already been adopted, or which may be adopted by the Arab League, in respect to the situation in Palestine." 32

With the completion of the armistice agreements, the Security Council expressed its satisfaction with the agreements, stating that they constituted an important step towards the establishment of permanent peace in Palestine, and expressing hope that the parties would aspire to reach agreement at the earliest possible time regarding all of their outstanding disputes. ${ }^{33}$

In spite of the Security Council's optimism, Israel and the Arab states disputed the significance of the armistice agreements. The Arab position was that the armistice did not terminate the state of war. ${ }^{34}$ They therefore had the rights of a belligerent in relation to Israel, including the right to boycott and block the passage of Israeli vessels or vessels sailing to Israel through the Suez Canal and through the Straits of Tiran leading to the port of Eilat. ${ }^{35}$ The Israeli position was that the armistice regime created a situation that was sui generis, deviating from a state of war, but not yet being a state of peace. ${ }^{36}$ The Security Council itself stated that "since the armistice regime ... is of a permanent character, neither party can reasonably assert that it is actively a belligerent." 37 It therefore ruled that Egyptian interference with the passage through the Suez Canal of goods destined for Israel was "inconsistent with the objectives of a peaceful settlement between the

the peace and ordered the establishment of a cease-fire.

32 Cablegram re Armistice Negotiations, ibid.

${ }^{33}$ The Palestine Question, SC Res. 73, UN SCOR, UN Doc. S/1376 II (1949) (reproduced in Moore, supra note 1 at 415).

34 "[T]he Armistice Agreements have neither de jure nor de facto . . terminated the state of war" in Husayn A. Hassouna, The League of Arab States and Regional Disputes: A Study of Middle East Conflicts (Dobbs Fery: Oceana Publications, 1975) at 304. See also Colloque de Juristes Arabes sur la Palestine, Alger, 22-27 Juillet 1967 - La Question Palestinienne, trans. by Edward Rizk (Alger: IM.J.,1968) at 114, 173 (French) [Colloque de Juristes Arabes sur la Palestine]. For an English translation, see Seminar of Arab Jurists on Palestine, Algiers, 22-27 July 1967: The Palestinian Question (Beirut: Institute for Palestinian Studies, 1968)

35 Colloque de Juristes Arabes sur la Palestine, ibid. at 170-196.

36 See Elyakim Rubinstein, "Israel-Lebanon - Peace or War," Haaretz (4 August 1983) (Hebrew) ["Israel-Lebanon - Peace or War"].

37 The Palestine Question, SC Res. 95, UN SCOR, 6thYear, Supp., UN Doc. S/2322 (1951) at 11 (reproduced in Moore, supra note 1 at 580, and in Lapidoth \& Hirsch, supra note 1 at 115) 
parties and the establishment of a permanent peace in Palestine." 38

The Israeli Supreme Court's position regarding the significance of the armistice agreements was not consistent and was arguably influenced by political developments after their conclusion. The initial view was that the armistice agreements terminated the state of war. Thus, in Jiday v. President of the Execution Office, Justice Goitien wrote on behalf of the Court:

[T]he underlying submission advanced by Counsel for the petitioner, that the two countries [Israel and Lebanon] are in a state of war, is completely unfounded. True, they may not yet have reached a state of peace, but those principles which forbid the maintenance of contacts with the enemy apply to a very different situation, namely, one of actual war. ${ }^{39}$

The judge based this conclusion on two legal considerations. First, "both Israel and Lebanon are Members of United Nations and are bound to conduct themselves in accordance with what is laid down in the Charter." 40 The judge relied on the UN Charter, and articles 33 and 37-38 in particular, to hold that "Members of the United Nations cannot be in a state of war until at least they have made some effort to reach agreement with their enemy or while the Security Council has not yet reached a decision concerning the state of

38 Ibid. For legal analyses of the armistice agreements between Israel and the Arab States, see Shabtai Rosenne, Israel's Armistice Agreements with the Arab States: A Judicial Interpretation by Shabtai Rosenne (Tel Aviv: Blumstein's Bookstores, 1951); Nathan Feinberg, The Legality of a "State of War" After the Cessation of Hostilities: Under the Charter of the United Nations and the Covenant of the League of Nations (Jerusalem: Magnes Press, 1961) at 45; Nathan Feinberg, The Arab-Israel Conflict in International Law: A Critical Analysis of the Colloquium of Arab Jurists in Algiers (Jerusalem: Magnes Press, 1970) at 79-84; Yoram Dinstein, Laws of War (Tel Aviv: Schocken, 1983) at 35-38, 41-42 (Hebrew); Yoram Dinstein, War, Aggression, and SelfDefense, 2d ed. (Cambridge: Cambridge University Press, 1994) at 43-46; and Hassouna, supra note 34 at 300-305. For the Arab boycott of Israel, see Dan S. Chill, The Arab Boycott of Israel: Economic Aggression and World Reaction (New York: Praeger Publishers, 1976).

39 H.C.J. 101/54, 22 I.L.R. 698 at 701, 9 P.D. 135 at 141 (Hebrew), online: The State of Israel, Judicial Authority $<$ http://elyon 1.court.gov.il/eng/verdict/framesetSrch.html> [Jiday].

$40 \quad$ Ibid. at 699. affairs which has come into existence between the two States."

The second, and more important legal source for Justice Goitien's conclusions was the IsraeliLebanese General Armistice Agreement. In this agreement, the parties confirmed that "[ $\mathrm{t}] \mathrm{he}$ injunction of the Security Council against resort to military force in the settlement of the Palestine question shall henceforth be scrupulously respected by both Parties." 42 The agreement further provided that "[n]o aggressive action by the armed forces of either party shall be undertaken, planned or threatened against the people or the armed forces of the other." 43 The the judge also stressed that " $[\mathrm{t}]$ he agreement establishes a general armistice between the armed forces of the two parties" and that "[n]o warlike act of hostility shall be conducted from territory controlled by one of the parties ... against the other."44 Finally, Justice Goitien stressed the importance of another provision, which stated that "[t]he present Agreement is not subject to ratification and shall come into force immediately upon being signed." 45

The combination of these two documents - the UN Charter and the armistice agreement between Israel and Lebanon - thus led the judge to the unequivocal conclusion that "[o] ur situation might properly be described as one of termination of war." ${ }^{46}$ Despite the legal nature of the Court's analysis of the status of the relations between Israel and Lebanon, it did not ignore its political implications. In acknowledging the political context, Justice Goitien wrote: "Furthermore,

\footnotetext{
Ibid. at 700

42 Ibid. at 700 . Justice Goitein noted that "[a]s in many other spheres, so in its relations with its neighbors the State of Israel is unique. It may not be possible to find any direct support for the submissions brought before us, neither in Oppenheim nor in any other book on public international law. But with Lebanon we have a particular Agreement, which clearly defines the legal aspects of relations between the two countries, and we must therefore first examine that Agreement very closely in order to accurately determine the legal nature of the relations subsisting between the two countries" (ibid. at 699). See also IsraeliLebanese General Armistice Agreement, supra note 24, art. I(1).

43 Jiday, ibid. See also Israeli-Lebanese General Armistice Agreement, ibid., art. I(2).

44 Jiday, ibid. See also Israeli-Lebanese General Armistice Agreement, ibid., art. III(3).

45 Jiday, ibid. See also Israeli-Lebanese General Armistice Agreement, ibid., art. VIII(1).

46 Jiday, ibid. at 701.
} 
when representatives of the government of Egypt appear before the Security Council and argue that they are entitled to prevent Israel ships from passing through the Suez Canal on the ground that a state of war exists between Egypt and Israel, the representatives of Israel always give the same answer: there is no state of war between Israel and her neighbors." 47

A similar ruling was given by the Tel Aviv District Court a year before judgment was given in the Jiday case. In Yudsin v. Estate of Shanti the Court ruled that:

The question ... is, does a state of war exist between Israel and Lebanon? . . . The fact is that upon the establishment of Israel the country was attacked by the Arab States, including Lebanon, and the Arab-Jewish war commenced. During a certain period there was a state of war between Israel and Lebanon and it was terminated by the signature of the General Armistice Agreement. However, no Peace Treaty has been signed. Nevertheless, I am not prepared to say that a state of war still subsists between Israel and the Arab States ... In my view, the war between Israel and Lebanon terminated no later than March 23, 1949, the date of the signature of the General Armistice Agreement. ${ }^{48}$

A different approach was adopted in two Supreme Court judgments given after 1982. In both cases, Supreme Court President Shamgar expressed reservation regarding the above ruling. In Tzemel v. Minister of Defence, Justice Shamgar ruled that "there is still a state of war" between Israel and Lebanon. ${ }^{49}$ This ruling was based on the judge's assumption that "an armistice agreement does not discontinue the state of war" and that, in order to do so, an additional agreement was

$47 \quad$ Ibid.

48 C.C. (T-A) 618/49, 19 I.L.R. 555. A summary of the decision has been published in 11 P.M. (Summaries) 98. The Court stressed the fact that no formal declaration of war was made. The question of the existence of a situation of war was therefore a factual one, to be decided by the court. Had a notice regarding the existence of war been published, "then only a notice regarding the termination of the war could lead to the exclusion of Lebanon from the definition of enemy State" (at 555-56).

49 H.C.J. 102/82, 37 P.D. 365 at 374 (Hebrew) [translated by author], abridged in 13 I.Y.H.R. 360, 20 Is.L.R. 514. required, such as "an agreement concerning the end of the state of war." 50 Justice Shamgar repeated this ruling in an obiter dictum in $\mathrm{Al}$ Nawarr v. Minister of Defence. ${ }^{51}$ He wrote:

[T]here is support for the opinion accepted by many of the legal scholars in the field of laws of war and also presented by Israel in the peace negotiations with Egypt, and in the similar, ill-fated negotiations with the Lebanese government - that even after the signing of armistice agreements, there must be a declaration to the effect that the state of war has terminated. ${ }^{52}$

As for the Jiday ruling, Shamgar J. conjectured that it was based upon the assumption, ostensibly valid at the time, that "the state of war had already terminated." ${ }^{, 53}$ However, he wrote that "we could hardly implement [the ruling in Jiday] ... today, under current circumstances, and in accordance with our current conceptions. ${ }^{, 54}$

Despite the armistice agreement, relations between Israel and Egypt had remained hostile. Hostilities were expressed in the boycott imposed by Egypt upon Israel, the blockage of the Suez Canal to Israeli sea vessels, the arming of the Sinai Peninsula which separates Israel and Egypt, and the Egyptian encouragement of terrorist acts against Israel. Egypt further declared that the armistice agreement had not terminated the state of war between Egypt and Israel. In this context, Israel defined its 1956 Sinai operation, in which it conquered the Sinai Peninsula, as an act of selfdefence. In the aftermath of the Sinai war, Israel withdrew its forces, without any new agreement having been signed with Egypt. Israel took this step despite Prime Minister David Ben Gurion's statement in the Knesset that the armistice agreement had expired and despite the foreign minister's proposal that Israel and Egypt sign an agreement regarding the "liquidation of belligerency" or "a non-aggression pact.."

\footnotetext{
Ibid.

1 H.C.J. 574/82, 39:3 P.D. 449 at 460 (Hebrew), abridged in 16 I.Y.H.R. 321, 22 Is.L.R. 224.

52 Ibid. [translated by author].

53 Ibid.

$54 \quad$ Ibid.

55 Medzini, supra note 16 at 541-97.
} 
The Six-Day War broke out between Israel and Egypt, Syria, and Jordan in 1967. Lebanon also participated in the fighting, while Iraq, Algeria, and Morocco sent troops. Further, Sudan declared war on Israel too. ${ }^{56}$ In the course of the war, Israel wrested the Sinai Peninsula from Egypt, the Golan Heights from Syria, and the West Bank from Jordan. Following the war, Israel declared that the armistice agreements that had been signed with the Arab states involved in fighting against Israel, i.e., Egypt, Syria, Jordan, and Lebanon, were null and void. ${ }^{57}$ The Security Council adopted a series of resolutions calling for a cease-fire.$^{58}$ These resolutions were followed by UN Security Council Resolution 242, entitled Concerning Principles for A Just and Lasting Peace in the Middle East. ${ }^{59}$ Resolution 242 called for, inter alia, the "[w]ithdrawal of Israel Armed Forces from territories occupied in the recent conflict" and the [t]ermination of all claims or states of belligerency." ${ }^{\prime 60}$ In this resolution, the Security Council acknowledged the right of every state in the region to "live in peace within secure and recognized boundaries." ${ }^{\prime 1}$

All of the belligerent parties, except for Iraq, approved the armistice regime declared by the Security Council. However, Resolution 242 did

56 Keesing's Contemporary Archives 1967-1968 (Bath: Longman Group, 1968) at 22135 .

57 Updates, Supplements and Appendices to Volumes 1-30, KitveiAmana (Israel Treaty Documents) [K.A.] (Hebrew) at 6-9. See also Moshe L. Dayan, "Between War and Peace" (10 August 1973) Haaretz (Hebrew). The UN, however, regarded the agreements as valid. See Nathan Feinberg, "The Transfer From War to Peace" (31 August 1973) Haaretz (Hebrew) (reprinted in Nathan Feinberg, Essays on Jewish Issues of Our Time (Jerusalem \& Tel Aviv: Dvir, 1980) 183).

58 The Situation in the Middle East, SC Res. 233, 234, 235 \& 236 , UN SCOR, 22d Year, Resolutions and Decisions of the Security Council, 1967 (New York: United Nations, 1967) at 2-4 [Resolutions and Decisions 1967] (reproduced in Moore, supra note 1 at 730-37, and in Lapidoth \& Hirsch, supra note 1 at 126).

59 UN SCOR, 22d Year, 2d mtg., UN Doc. S/8226 (1967), Resolutions and Decisions 1967, ibid. at 8-9 [Resolution 242] (reproduced in Moore, ibid. at 1034, and in Lapidoth \& Hirsch, ibid. at 134)

60 Ibid.

${ }^{61}$ Ibid. There is a discrepancy between the English and French versions of Resolution 242, which led to disagreement as to the meaning of section 1(i) of the Resolution. While the English version called for Israel's withdrawal "from territories occupied in the recent conflict," the French version calls for " $[\mathrm{r}]$ etraite des forces armées israéliennes des territoires occupés lors du récent conflict" [emphasis added]. See Asher Maoz, "Application of Israeli Law to the Golan Heights Is Annexation" (1994) 20 Brooklyn Journal of International Law 355 at 356 , note 2 . not lead to negotiations for a peace agreement, and hostilities between Egypt and Israel continued. Ultimately, the armistice between Israel and Syria and between Israel and Egypt collapsed in 1973 with the outbreak of the October War. In addition to the Egyptians and Syrians, forces from Iraq, Algeria, Morocco, Libya, and Sudan also participated in the war. The October War was terminated with the adoption of UN Security Council Resolution $338 .{ }^{62}$ This resolution called for "negotiations ... aimed at establishing a just a durable peace in the Middle East" $"$ and ultimately led to the Egyptian-Israeli Agreement on Disengagement of Forces ${ }^{64}$ and the Agreement on Disengagement Between Israeli and Syrian Forces. ${ }^{65}$ The striking difference between the two agreements is that while the agreement with Syria was limited to military arrangements for the separation of forces, the agreement with Egypt was expressly concerned with moving towards peace in its stipulation that " $[t]$ his agreement is not regarded by Egypt and Israel as a final peace agreement. It constitutes a first step toward a final, just and durable peace." ${ }^{66}$ After an additional interim agreement between Israel and Egypt, ${ }^{67}$ the two states signed a Treaty of Peace on 26 March 1979. ${ }^{68}$ Article 1 of the Treaty stated that " $[t]$ he state of war between the Parties will be terminated

62 Cease-Fire in the Middle East, SC Res. 338, UN SCOR, 28th Year, Resolutions and Decisions of the Security Council, 1973 (New York: United Nations, 1973) at 10 (reproduced in Moore, supra note 1 at 1137 , and in Lapidoth \& Hirsch, supra note 1 at 145$)$.

63 Ibid

64 Letter Dated 18 January 1974 From the Security-General Addressed to the President of the Security Council, UN SCOR, UN Doc. S/1198 (1974) [Letter, 18 January 1974] (reproduced in Moore, ibid. at 1166, and in Lapidoth \& Hirsch, ibid. at 149).

65 Report of the Secretary-General concerning the Agreement on Disengagement between Israeli and Syrian Forces, UN SCOR, UN Doc. S/11302/Add. 1-3 (1974) (reproduced in Moore, ibid. at 1193 , and in Lapidoth \& Hirsch, ibid. at 152).

66 Letter, 18 January 1974, supra note 64.

${ }^{67}$ Agreement between Egypt and Israel [concerning Sinai and the settlement of the dispute], 2 September 1975, UN Doc. S/11818/Add. 1 (reproduced in Moore, ibid., vol. 4 at 5, and in Lapidoth \& Hirsh, ibid. at 161).

${ }^{68}$ Treaty of Peace between the Arab Republic of Egypt and the State of Israel, 26 March 1979, 1138 U.N.T.S. 17855 at 72-75 (reproduced in Moore, ibid. at 347, and in Lapidoth \& Hirsch, ibid. at 218). This agreement was preceded by the $1978 \mathrm{Camp}$ David documents, which included A Framework for Peace in the Middle East Agreed at Camp David, Egypt and Israel (17 September 1978, 1138 U.N.T.S., 17853 at 39-45 (reproduced in Moore, supra note 1 at 307 , and in Lapidoth \& Hirsch, ibid. at 195); and A Framework for the Conclusion of a Peace Treaty between Egypt and Israel (17 September 1978, 1138 U.N.T.S. 17854 at 53-56 (reproduced in Moore, ibid. at 313, and in Lapidoth \& Hirsch, ibid. at 200). 
and peace will be established between them upon the exchange of instruments of ratification of this Treaty." ${ }^{\prime 69}$ The instruments of ratification were exchanged and the Treaty came into force on 25 April 1979.

The next peace treaty was signed between Israel and Jordan on 26 October $1994 .{ }^{70}$ In article 1 of the treaty, the parties declared the establishment of peace between themselves with the signing of the treaty. Prior to signing the peace treaty, the parties signed the Washington Declaration in which they stated that "the extended dispute between the parties is now coming to an end, and in this spirit, the state of hostility between Israel and Jordan has been terminated." 71

Two neighboring states remained with whom Israel had not signed peace agreements: Syria and Lebanon. However, on 17 May 1983, following the Lebanese war, the agreement known as the Khaldeh Agreement (after the place where the signing took place) was signed between the government of the State of Israel and the government of the Republic of Lebanon. ${ }^{72}$ The agreement declared "the importance of maintain-

69 Treaty of Peace between the Arab Republic and the State of Israel, ibid.

70 Treaty of Peace Between the State of Israel and the Hashemite Kingdom of Jordan, 26 October 1994, U.N.T.S. 35325 (reproduced in Medzini, supra note 16, vol. 14 at 826, and in Bernard Reich, ed., Arab-Israeli Conflict and Conciliation: A Documentary History (Westport: Praeger Publishers, 1995) at 263). Regarding the peace treaty between Israel and Jordan, see Elyakim Rubinstein, "The Road to Israeli-Jordanian Peace"(1998) 14 Bar-Ilan Law Studies 527 (Hebrew), andElyakim Rubinstein "The Israel-Jordan Treaty of Peace" (1996) 3 Hamishpat 347 (Hebrew).

71 Washington Declaration, 25 July 1994, (Annex) UN Doc. A/49/300-S/1994/393 (reproduced in Medzini, ibid., vol. 14 at 716 , and in Reich, ibid. at 252). Israel requested that the Washington Declaration refer explicitly to the " $[\mathrm{t}]$ ermination of the state of war," this having been the terminology used in the peace agreement with Egypt. Jordan on the other hand requested that the phrase "[t]ermination of the state of Belligerency" be used, in the light of the wording in Resolution 242 (supra note 59). The compromise reached was that the declaration adopted the Jordanian wording, but in his speech at the White House King Hussein stated that "both in Arabic and in Hebrew, our people do not have such a term ["end of the state of Belligerency"]. What we have accomplished and what we are committed to is the end of the state of war between Jordan and Israel" (Medzini, ibid. at 721). See also, Elyakim Rubinstein, The Peace Between Israel and Jordan: Anatomy of Negotiations (Tel Aviv: Mordechai Jaffe Center for Strategic Studies, Tel Aviv University, 1996) at 11 (Hebrew).

72 Israel-Lebanon: Agreement on Withdrawal of Troops from Lebanon (reproduced in (1983) 22 I.L.M. 708, and in Lapidoth \& Hirsch, supra note 1 at 299) [Khaldeh Agreement]. ing and strengthening international peace," and it included mutual undertakings "to respect the sovereignty, political independence and territorial integrity" of both states. ${ }^{73}$ The parties further confirmed "that the state of war between Israel and Lebanon has been terminated and no longer exists." $" 74$ The parties declared that "being guided by the principles of the Charter of the United Nations and of International Law, [they] undertake to settle their disputes by peaceful means in such a manner as to promote international peace and security, and justice." ${ }^{, 75}$

According to Elyakim Rubinstein, a member of and legal advisor to the delegation for talks with Lebanon, the agreement did not constitute the complete fulfillment of Israel's political [diplomatic] goals at that time, i.e., an agreement that could be viewed as a peace agreement with an additional Arab state. It was nonetheless an agreement of a political nature, comprising the central features of relations that are referred to as relations of peace between states. ${ }^{76}$

The problem was that in contravention of its provisions, and due to Syrian opposition, the Lebanese parliament never ratified this agreement. Hence, according to an internal memorandum prepared by the legal department of the Israeli foreign ministry, the agreement never came into force. $^{77}$ Furthermore, in 1989 the Al-Taif Agreement Concerning Lebanon was ratified in Saudi Arabia. ${ }^{78}$ This agreement called for "[a]dopting all the necessary measures for liberating all Lebanese territories from Israeli occupation" 79 and was interpreted as an "expression of Lebanese consent to permit the use

76 Elyakim Rubinstein, Paths of Peace (Tel Aviv: The Ministry of Defence Publishing House, 1992) at 311 (Hebrew) [translated by author].

77 Enemy States According to International Law and Israeli Law, Internal memorandum prepared by the legal department, Israel Ministry of Foreign Affairs [unpublished] (Hebrew) [Internal Memorandum]. In writing this section I drew extensively on the article of the legal advisor of the foreign ministry, Alan Baker, entitled "The Development of the Peace Process Between Israel and its Neighbours" (1998) 14 Bar-Ilan Studies 493 (Hebrew).

7822 October 1989 (reproduced in Lapidoth \& Hirsch, supra note 1 at 366 ).

79 Ibid., s. 3
} 
of Lebanese territory by fighters against Israel." ${ }^{\prime 0}$ It was on this basis that the foreign ministry memorandum determined that "according to International Law, Lebanon is currently in a state of war with Israel" and that under Israeli law "Lebanon is an enemy state." determined that under the provisions of international law, "Israel and Syria are in a state of war" and that Syria is "an enemy state" under Israeli law. Under the rubric of international law, the memorandum also stated that "Israel and Iraq are in a state of war." $" 82$ This conclusion was based upon the bombing of civilian Israeli targets with Scud missiles during the 1991 Gulf War, in addition to Iraqi participation in the three major wars against Israel in 1948, 1967, and $1973 .{ }^{83}$

On the other hand, the memorandum concluded that Israel was not in a state of war with Saudi Arabia, despite Saudi Arabia's participation in combat against Israel and despite the fact that it permitted public fundraising within its borders to support terrorist organizations. This position was based upon "Saudi Arabian declarations of support for the peace process and its indirect trade relations with Israel." ${ }^{\circ 4}$ In the same vein, the memorandum stated that " $[t]$ here is no state of war between Israel and Yemen," ${ }^{85}$ despite Yemen's participation in the Arab League Declaration in favour of the Arab states' invasion of Israel in 1948, and despite media articles calling for Israel's destruction. Accordingly, given the "limited" nature of Libyan and Algerian participation in the battle against Israel, the memorandum stated that " $[t]$ he scope of combat is not sufficient ... to determine that in terms of

\footnotetext{
80 Internal Memorandum, supra note 77 [translated by author]. The memorandum was written prior to the conquest of Iraq, by American and allied forces in 2003.

81 Internal Memorandum, ibid. In a long array of statutes, the terms "enemy," "enemy state," "land of the enemy," and "armed" are defined a number of different ways, including as those who are fighting against Israel, or who maintain a state of war with Israel, or who have declared themselves as fighting against Israel. See e.g. Penal Law: 1977, L.S.I. 5737/1977, special vol., s. 91 [Penal Code]; Trading with the Enemy Ordinance 1939, P.G. [Palestinian Gazette] 1939, s. 2(1)(b), as amended by the Defence Legislation (Incorporation in Certain Ordinances), 1945, P.G. 1945 at 134; Military Justice Law, 1955, L.S.I. 1955, vol. 9 at 184; and Import and Export Ordinance (New Version) 1979, L.S.I. (new version) 1979, vol. 3 at 116 , s. 1(a).

${ }^{82}$ Internal Memorandum, ibid.

83 Ibid.

${ }^{84}$ Ibid.

${ }^{85}$ Ibid.
}

International Law, these states are in a state of war with Israel." ${ }^{86}$ This position was also adopted regarding Morocco, which, despite its participation in the war against Israel in 1967 and in 1973, had since then conducted relations with Israel, including maintenance of a liaison office that operated until the outbreak of the unrest in September 2001 between Israel and the Palestinians. Finally, regarding Sudan, which had declared war on Israel in 1967 and sent forces to participate in the fighting in 1973, the memorandum stated that "[t]here [was] no state of war from the perspective of International Law." ${ }^{87}$ This conclusion was based upon the "changed tone" in the Sudanese declarations, including support of the peace process, despite the fact that Sudan continued to impose an economic boycott on Israel and allowed the terrorists to maintain training camps in its territory. ${ }^{88}$

The foreign ministry's determination regarding the existence of a state of war between Israel and Syria and between Israel and Lebanon relied upon the judgment of the Haifa District Court in Cr. C. $1056 / 97 .{ }^{89}$ The Court was required to decide whether Lebanon was an "enemy" within the meaning of section 91 of the Penal Code of 1977..$^{90}$ A legal opinion was prepared by the head of the International Law Branch of the Israel Defence Forces (IDF) Legal Division, Colonel Daniel Reisner, and submitted to the Court. It determined that a state of war existed between Israel and Lebanon. Reisner based his opinion on the fact that, by participating in the 1967 war against Israel, Lebanon "abrogated the armistice agreements between Israel and Lebanon and created a new and clear situation of combat between the two states." $" 91$ The Khaldeh Agreement did not terminate that situation since it did not come into force. This position was supported by the legal opinions of Ambassador Alan Baker, the legal advisor of the Ministry of Foreign Affairs, ${ }^{92}$ and by an article written by Elyakim Rubinstein, the former attorney general of the State of Israel and the previous legal advisor of the foreign

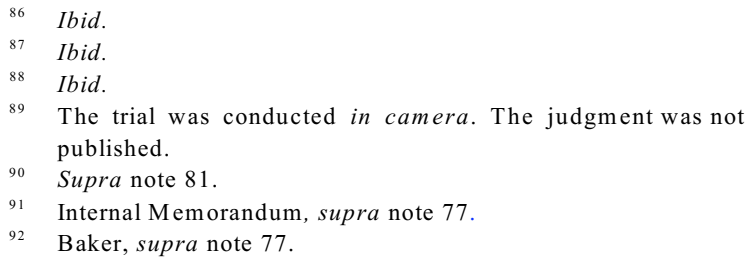


ministry. ${ }^{93}$ An opposing legal opinion was presented to the Court, prepared by Yoram Dinstein, a professor of international law at the Buchmann Faculty of Law, Tel Aviv University. At the core of the dispute were two questions. First, had Lebanon participated in the 1967 War against Israel? Second, if Lebanon had been a participant in the war, did it terminate its armistice agreement with the State of Israel? The parties further disputed the significance of the Khaldeh Agreement, though they agreed that it would have terminated the state of war between Israel and Lebanon, had the agreement become effective.

Professor Dinstein's position was that the armistice agreement terminated the state of war between Israel and Lebanon, despite the fact that it had not been formally ratified and brought into force. He justified this view with the language adopted in section 1(2) of the Khaldeh Agreement under which " $t]$ he parties confirm that the state of war between Israel and Lebanon has been terminated and no longer exists." ${ }^{, 94}$ On the basis of this provision, Dinstein wrote:

The non-ratification of the Agreement does not affect its determination, made in the form of confirmation of the given fact, that the state of war between the two states was terminated prior to 1983 (before the signing of the Khaldeh Agreement). Absent a requirement of ratification as a condition for the Agreement's validity, its non-ratification does not affect the determination that the state of war had long since ended . . . already in 1949, in other words with the armistice agreement with Lebanon. ${ }^{95}$

The Court rejected Professor Dinstein's claim, ruling:

[T] he participation of Lebanon in the Six Day War, shoulder to shoulder with the other enemy states of Israel, e.g. Syria, Jordan and Egypt, had the effect of terminating the Armistice Agreement between Israel and Lebanon and creating

\footnotetext{
93 "Israel-Lebanon - Peace or War," supra note 36.

94 Supra note 72.

95 Quoted in Cr.C. 1056/97, supra note 89 [translated by author].
}

a new and clear situation of war between the two states - Israel and Lebanon. ${ }^{96}$

The Court went on to declare that the Khaldeh Agreement did not change this situation since it was not ratified by the parties and therefore did not come into effect. The Court marshaled further support for its ruling that Lebanon was an enemy state by the fact that Lebanon was not an independent state, but rather "a satellite state of Syria ... and its extended arm." ${ }^{97}$ As regards Syria, there was "certainly no dispute that it is an enemy state to Israel." 98

\section{THE LAW OF GOING TO WAR}

\section{INTRODUCTION}

The practice of waging war in the Middle East, as in the other parts of the world, was affected by the proscription on the use of force in the resolution of international disputes, ${ }^{99}$ except where necessitated by self-defence. ${ }^{100}$ The proscription of war meant that states no longer adopted the technical procedure of declaring war, and that wars in the formal sense were replaced by wars in the substantive sense. One commentator has even suggested that "the technical concept of war" be replaced by "the factual concept of armed conflict," claiming that "[i]t is doubtful . . . whether it is still meaningful to talk of war as a legal concept or institution at all. If no direct legal consequences flow from the creation of a state of war, the state of war has become an empty shell which International Law has already discarded in all but name." ${ }^{101}$ The reason for this evolution is that in a contemporary context:

[T] he application of the laws of war does not depend upon the recognition of the existence of a formal state of 'war,' but (with certain qualifications) contemplates situations of armed conflict whether or

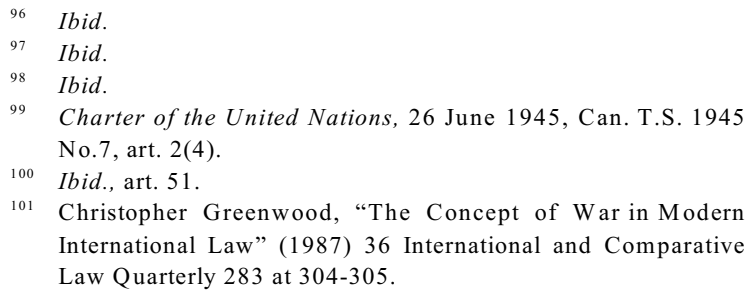

101 Christopher Greenwood, "The Concept of War in Modern International Law" (1987) 36 International and Comparative Law Quarterly 283 at 304-305. 
not formally declared or otherwise recognized as 'war., 102

The upshot is that no practice of declaring war necessarily exists in the Middle East, even though the region has been in an almost permanent state of armed conflict.

Similarly, though the governments of the member states of the Arab League made their declaration regarding the invasion of Palestine with the intention of frustrating the establishment of the Jewish State pursuant to the decision of the UN General Assembly, ${ }^{103}$ they did not declare war in the classical sense. Their declaration and accompanying invasion did not even relate to the establishment of the State of Israel. ${ }^{104}$ Instead, the actions of the Arab League were purportedly occasioned by the fact that "the Mandate over Palestine ha[d] come to an end, leaving no legally constituted authority behind." ${ }^{105}$ The Arab League further stated that the Partition Plan had been adopted "contrary to the United Nations' Charter," "106 justifying their invasion on the basis of the Arab League's status as "a regional organization within the meaning of provisions of Chapter VIII of the Charter of the United Nations." As such, the governments of the Arab states were "responsible for maintaining peace and security in their area." 107 Accordingly, the Arab states expressed "great confidence that their action [would] have the support of the United Nations; [that it would be] considered as an action aiming at the realization of its aims and at promoting its principles, as provided for in its Charter." 108

102 A. Roberts \& R. Guelff, Documents on the Laws of War, $3 \mathrm{~d}$ ed. (Oxford: Oxford University Press, 2000) at 2.

103 Cablegram of the League of Arab States, supra note 16.

104 In fact, the decision was adopted at a secret meeting in Lebanon, on the 19 September 1947, more than two months prior to UN General Assembly Resolution 181(II), supra note 7. See Boutros Y. Boutros-Ghali, The Arab League, 1945-1946 (New York: Carnegie Endowment for International Peace, $1954)$ at $384,411$.

105 Cablegram of the League of Arab States, supra note 16.

$106 \mathrm{Ibid}$. For the substantiation of the Arab claim regarding the legal invalidity of the Partition Plan, see Colloque de Juristes Arabes sur la Palestine, supra note 34 at 80-217. For a critique of these claims, see Nathan Feinberg, The Arab-Israel Conflict in International Law, supra note 38 at 55-71.

107 Cablegram of the League of Arab States, ibid.

108 Ibid. See also Hassouna, supra note 34 at 278-79.

\section{ISRAELI LAW OF GOING TO WAR}

Israeli law regarding the initiation of a war may be divided into three periods:

a) from the establishment of the State of Israel until 1968,

b) from 1968 until 1992, and

c) following 1992 .

\section{A) The Power to Go to W AR UNTIL 1968}

The Declaration of the Establishment of the State of Israel set up the People's Council as the Provisional Council of State and the People's Administration as its provisional government, "until the establishment of the elected, regular authorities of the State."109 Once the Knesset, was elected, section 12 of the Transition Law $1949^{110}$ conferred the powers of the provisional government to the elected government. Prior to that transition, the first comprehensive legislative act to be adopted by the Provisional Council of State was the Law and Administration Ordinance 1948. ${ }^{111}$ The sixth chapter of this statute dealt with "Armed Forces." It comprised a single section, section 18, which stated that "[ $\mathrm{t}]$ he Provisional Government may establish armed forces on land, on the sea and in the air, which shall have the authority to do all lawful and necessary acts for the defence of the State." 112

It was on the basis of this statute that the Defence Army of Israel Ordinance $1948^{113}$ was passed. The Defence Ordinance was silent regarding the subordination of the army to the branches of the civil government, but this subordination may be inferred from the obligation imposed upon "[e]very person serving in the Defence Army of Israel ... [to] take an oath of allegiance to the State of Israel, its Constitution

\footnotetext{
109 Declaration of the Establishment of the State of Israel, supra note 1 .

110 L.S.I. 5709/1949, vol. 3, 3.

111 L.S.I. 5708/1948, vol.1, 7.

112 Ibid.

113 The ordinance was first published by the provisional government (L.S.I. 5708/1948, vol. 1, 15) and was therefore ultra vires; however, it was subsequently ratified by the Provisional Council of State in The Law and Administration (Further Provisions Ordinance), L.S.I. 1948, vol. 1, 26 [Defence Ordinance].
} 
and its competent authorities." ${ }^{114}$ Nor did the Defence Ordinance deal with the division of powers between the civil level and the military level, except for its provision that " $[\mathrm{t}] \mathrm{he}$ Minister of Defence is charged with the implementation of this Ordinance." ${ }^{115}$ Finally, the Defence Ordinance did not make any provisions regarding the power to begin a war. However, a possible source for this power may be found in section 14(a) of the Law and Administration Ordinance 1948, which provided that:

Any power vested under the law in the King of England or in any of his Secretaries of State, and any power vested under the law in the High Commissioner, the High Commissioner in Council, or the government of Palestine, shall henceforth vest in the Provisional Government, unless such power has been vested in the Provisional Council of State by any of its Ordinances. ${ }^{116}$

In the legal literature, this section was interpreted as conferring prerogative powers on the Israeli government. The scope of these powers, however, is disputed. According to one view, it was only the prerogative powers expressly conferred under British legislation to the High Commissioner of Palestine that were subsequently transferred to the Israeli government. ${ }^{117}$ There was also a dispute as to whether the intention was to transfer a set of powers strictly limited to those effective during the period of the British Mandate over Palestine by virtue of the laws of Palestine, or alternatively, whether the Law and Administration Ordinance also transferred the royal prerogatives in England itself, by virtue of English law. Justice Silberg of the Supreme Court of Israel was of the opinion that:

[T]he words "any power" meant any power given in Mandatory Palestine until the establishment of the State, in accordance with the laws of Palestine, and

\footnotetext{
114 Defence Ordinance, ibid., s. 3. See also Ariel Bendor \& Mordechai Kremnitzer, The Basic Law: The Army (Jerusalem: The Harry and Michael Sacher Institute for Legislative Research and Comparative Law, 2000) at 29 (Hebrew).

115 Defence Ordinance, ibid., s.7.

116 Supra note 111.

117 See Benjamin Aktzin, "The Prerogative Power in the State of Israel” (1950) 7 Hapraklit 566 (Hebrew).
}

not every power which it had, and which it still has under English law, in England itself or within the boundaries of the empire. $^{118}$

In other words, Silberg J. found it inconceivable that this ordinance was intended to effect a transfer of the full wide range of English powers, including royal prerogative, to the Israeli government.

Professor Amnon Rubinstein took the opposite position and explained his reasoning as follows:

The language of the section indicates... the conclusion that the Legislator intended to transfer all of the powers residing in the English Crown, including its prerogative powers, to the Israeli government. .. This conclusion is also fortified by the reasoning that in the absence of this transfer, the government would be lacking a number of critical powers on the level of international relations. The mandatory government was not the government of an independent state, but rather the government of a ward state. Under the laws of Palestine it did not have the authority to declare war, nor could it conclude international treaties in its own name. ${ }^{119}$

Rubinstein added that "[w]ere we to adopt Justice Silberg's approach that only powers residing in the Crown under the Palestinian Law were transferred to the government of the State of Israel, we would leave it powerless in numerous areas." "120 Accordingly, "the broad view should be adopted, which confers the Israeli government with the powers of the Crown in England under

\footnotetext{
118 Gorali v. Diskin, C.A. 19/54, 8 P.D. 521 at 526 (Hebrew) [translated by author].

119 The Constitutional Law of the State of Israel (Tel Aviv: Schocken, 1969) at 222-26 (Hebrew) [translated by author].

120 Ibid.
} 
English Law."121 Alternatively, Rubinstein suggested that the power to begin a war might be founded in "the powers conferred upon any government of a sovereign state, within the International Law, without explicit empowerment in the Israeli Law." 122

Finally, it was suggested that the government powers, including its powers regarding foreign policy and the power to declare war, be entrenched within the general powers of government, or as part of its inherent powers. As then Justice Minister Yaakov-Shimshon Shapira explained, "[t]he government has powers with two characteristics: statutory powers which were explicitly given to it by law and inherent powers, which flow from its very nature and the totality of its roles as a government." ${ }^{123}$ Regarding the source of the inherent powers, the Supreme Court President Meir Shamgar wrote:

Various scholars have attributed the theory of "general" or "inherent" government powers to the tradition of the prerogative of the British monarchy, as expressed in our common law. In my view the power inevitably arises from the establishment of the state and its authorities, in other words, from the actual establishment of an independent national framework which is administered by a government ... with no need for roots in foreign laws. ${ }^{124}$

However, this approach was challenged, the claim being that the Law and Administration Ordinance was enacted on the assumption that the government is subject to the ultra vires doctrine, which requires specific powers to be conferred explicitly, including the authority to establish

121 Ibid. Another possibility is the absorption of the prerogative powers under English Common Law, through s. 46 of the Kings' Order in Council for the Land of Israel, Laws of Palestine 1922-1947, vol. 3, 2569, which refers to this source in the absence of any statutory arrangement under local law (see ibid. at 227-28). For a critical analysis of the absorption of the prerogative in Israeli law, see Margit Cohn, General Powers of the Executive Branch (Jerusalem: The Harry and Michael Sacher Institute for Legislative Research and Comparative Law, 2002) at 152-60 (Hebrew)

122 Rubinstein, supra note 119 at 230.

123 D.K. 1966, vol. 46 at 1778.

124 Federman v. Minister of Police, H.C.J 5128/94, 48 P.D. 647 at 653 (Hebrew) [Federman] [translated by author] armed forces that was provided for in the ordinance. ${ }^{125}$

\section{B) The Power to Initiate War, 1968- 1996}

In 1968, the Knesset passed the Basic Law: The Government. Section 29 of this law, entitled "Powers of Government," stated that "[t]he Government is competent to perform in the name of the State and subject to any law, all actions which are not legally incumbent on another authority."126 The legal literature raised the possibility that "this section [was] intended ... exclusively for the exercise of powers and it releases the government from the doctrine of ultra vires." ${ }^{127}$ As a result, "it [did] not confer power to the government; rather, it establishe[d] that the government is an organ of the state, in other words, that it is entitled to exercise powers conferred upon the state by another source." 128 However, the governing opinion was that "the section itself is a source of authority," 129 and that "the various general powers of government required for the management of state affairs can be anchored [therein]." ${ }^{130}$ Section 29 of the 1968 Basic Law can therefore be regarded as the source of the government's powers on the international level, including the authority to go to war. ${ }^{131}$ This conclusion is fortified by the determination appearing in section 1 of the Basic Law: The Government, which bears the title "What the Government Is" and states that "[t]he Government is the executive authority of the State."

The authority to go to war was again an issue in 1976, when the Knesset passed the Basic Law: The Army. ${ }^{133}$ This Basic Law was passed following the recommendations of the Commission of Enquiry established to investigate

125 See Rubinstein, supra note 119 at 231

126 Basic Law: The Government (1968), supra note 4.

127 Rubinstein, supra note 119 at 231

128 Itzhak Zamir, Administrative Power (Jerusalem: Nevo, 1996) vol. 1 at 335 (Hebrew) [translated by author].

129 Ibid.

130 Baruch Bracha, Administrative Law (Tel Aviv: Schocken, 1986) vol. 1 at 52 (Hebrew) [translated by author]. See also Federman, supra note 124 at 653.

131 The subcommittee for Basic Laws of the Constitution, Law and Justice Committee, explicitly noted that s. 29 is also required in the areas of security and foreign relations, similar to the English royal prerogative (D.K. 1968, vol. 52 at 3101-103).

132 Basic Law: The Government (1968), supra note 4.

133 L.S.I. 5736/1970, vol. 30, 150 [Basic Law: The Army (1976)]. 
the Yom Kippur War incidents, chaired by Simon Agranat, then President of the Supreme Court. Although the Agranat Commission viewed section 29 of the Basic Law: The Government as establishing the government's responsibility for army activities, it determined that:

[T]here are no clear definitions for the allocation of powers, duties and responsibilities among the three authorities dealing with security matters, i.e., the government and the prime minister, the minister of defence and the chief of staff which heads the IDF, and for establishing the relationship between the political leadership and the supreme command of the IDF. ${ }^{134}$

The Basic Law: The Army does not deal with the power to declare war and with its conduct, only determining the subordination of the army to the government and the minister of defence. Consequently, the legal position prior to its adoption remained unchanged, and the power to declare war continued to be entrusted to the government, as it had been prior to the enactment of this Basic Law. ${ }^{135}$ The government's powers regarding the initiation and conduct of war were thus a part of its general powers; this raised the acute problem of the absence of any explicit restrictions on the power of the government. ${ }^{136}$ Furthermore, there was no reference at all to parliamentary supervision over the actions of the government in that area.

\section{c) The Power to Start War after 1996}

In 1992 the Knesset passed the Basic Law: The Government ${ }^{137}$ which replaced the Basic Law: The Government from 1968. This Basic Law came into force in 1996, before the elections for the fourteenth Knesset. In 2001, the Knesset replaced the 1992 Basic Law with a new Basic Law, which came into effect in 2003 , before the elections for

134 Report of the Commission of Enquiry - The Yom Kippur War, (Tel Aviv: Am Oved, 1975) at 25-26 (Hebrew) [translated by author].

135 See Shimon Shetreet, "The Grey Area of War Powers: The Case of Israel" (1988) 45 Jerusalem Quarterly 27 at 37.

136 Rubenstein, supra note 119 at 233.

137 Basic Law: The Government (1992), supra note 5. the sixteenth Knesset. ${ }^{138}$ These Basic Laws included provisions regarding the residual authority of the government, previously established through section 29 of the 1968 Basic Law. They appear as section 40 in the 1992 version and section 32 of the 2001 version. In the 1992 version, the section is entitled "Powers of Government;" "139 in the 2001 version, this section is entitled "Residual Powers of Government."140

These two Basic Laws also included specific provisions governing the initiation of war. Section 51 of the 1992 Basic Law (which became section 40 in the 2001 version), entitled "Declaration of War," provides that:

(a) The State may only begin a war pursuant to a government decision.

(b) Nothing in the provisions of this section will prevent the adoption of military actions necessary for the defence of the State and public security.

(c) Notification of a government decision to begin a war under the provision of subsection (a) will be submitted to the Knesset Foreign Affairs and Security Committee as soon as possible; the Prime Minister also will give notice to the Knesset plenum as soon as possible; notification regarding military actions as stated in subsection (b) will be given to the Knesset Foreign Affairs and Security Committee as soon as possible. ${ }^{141}$

Addressing this section, the president of the Supreme Court, Justice Aharon Barak, ruled that "[t]he Government is the executive branch of the State. By virtue of this power, and other powers given to it (see e.g., sections 40 and 51 of the Basic Law: The Government (1992)) the

38 Basic Law: The Government, S.H. 5761/1992, 168 [Basic Law: The Government (2001)]. The multiple versions of Basic Law: The Government were a result of changes of the system of government in Israel. In 1992 the parliamentary system was replaced by a mixed parliamentary regime, in which the prime minister was elected directly by the citizens. In 2001, Israel reverted to the system of government by parliament.

139 Basic Law: The Government (1992), supra note 5.

140 Basic Law: The Government (2001), supra note 138.

141 Basic Law: The Government (1992), supra note 5. 
Government is authorized to conduct the foreign and security policy of the State." ${ }^{142}$

Despite its title, "Declaration of War," the term does not reappear in the section itself. Instead, the section deals with two situations: "to begin a war" and "military actions." The Knesset did not define these terms, apart from stating that the "military actions" referred to are those "necessary for the defence of the state and public security." The basic difference between the two categories of military actions referred to in section 40 of the Basic Law is that only the decision to "begin a war" requires a government decision. Nonetheless, the precise distinction between "war" and "military action" is not sharp. Referring to the need to obtain a government decision regarding the starting of a war, Ben Meir writes that "[i]t still leaves enough leeway under section [40(b)] for extensive military operations without a formal government decision to go to war." "143 It would seem that the power to decide on starting a war was given to the government plenum due to the far-reaching consequences of such a decision. It thus seems logical to interpret the term objectively - in other words, not in accordance with the subjective intention escorting the initiation of the military action, but rather as "an action that the enemy is liable to regard as starting a war."144 Despite the somewhat loose wording, section 40(a) of the 2001 Basic Law is of essential importance. ${ }^{145}$

The requirement of "a government decision" to "begin a war" seems to indicate that this does not apply to actions governed by section 40(b) of the 2001 Basic Law. In fact, it was suggested that actions of this nature "may be adopted at the

142 Weiss v. Prime Minister, H.C.J. 5167/00, 55 P.D. 455 at 471 (Hebrew) [Weiss, translated by author].

143 Yehuda Ben-Meir, Civil-Military Relations in Israel (New York: Columbia University Press, 1995) at 59.

144 Nun, supra note 6 at 122, footnote 150 [translated by author].

145 Prior to the introduction of this section, there was one case in which the decision to initiate a war was kept secret, and only divulged to some of the cabinet ministers immediately before the outbreak of hostilities, but this precedent was never repeated. This happened in relation to the Sinai Operation in 1956; see Gavriela Heichal, Civil Control over the Israeli Defence Forces 1945-1967 (Jerusalem: Ariel, 1998) at 181-184 (Hebrew). The Director of the Government Newspaper Bureau at that time, Meron Medzini, wrote: "In accordance with its best traditions, Israeli decision makers operated in a conspiratorial manner and did not involve the government in the proceedings" (The Proud Jewess: Golda and the Israeli Vision (Jerusalem: Idanim, 1990) at 239 (Hebrew) [translated by author]). exclusive discretion of the military authorities." 146 This guideline appeared "overly broad," leading Bendor and Kremnitzer to suggest that sections 51(b) and 40(b) of the 2001 Basic Law be interpreted "as relating to an urgent act of defence in a battle initiated by the enemy." 147 These authors further claimed that initiation of military activity not constituting war is within the power of the minister of defence, under section 2(b) of the 1976 Basic Law: The Army, which stipulates that the minister of defence is in charge of the army on behalf of the government. Finally, it has been argued that "where an enemy began a war ... the Minister of Defence may continue operations and broaden or limit its goals and their extent, without specific approval." 148

I do not concur with this opinion. Broadening the goals and scope of a war initiated by the enemy has political ramifications, and is not a matter of military tactics. Such a decision, as opposed to action to drive back the enemy, should be a governmental decision. In my view, given that section 40(b) of the Basic Law: The Government (2001) does not specify the particular authority empowered to take military defensive action, then an action of that kind automatically falls within the government's residual authority, as an action not legally incumbent on another authority under section 32 of the Basic Law. The difference between the power to begin a war and the power to take defensive military measures is that the former cannot be delegated by the government to others, whereas the government may delegate the latter to some of its ministers. This emerges from the language of section 33(a) of the Basic Law: The Government (2001), which states that "[p]owers granted by law to the Government may be delegated to one of the Ministers; this does not apply to powers granted in accordance with this Basic Law except for powers under section 32."149

As a matter of fact, the government frequently delegates this power to the Ministerial National Security Committee instead of exercising it by way of the government plenum. (In journalese, the

\footnotetext{
146 Bendor \& Kremnitzer, supra note 114 at 44-45 [translated by author].

147 Ibid.

148 See Nun, supra note 6 at 123.

149 Supra note 141.
} 
Committee is known as the Security Cabinet.) The Ministerial National Security Committee was first established by the Basic Law (Amendment No. 8): The Government, passed in $1991 .{ }^{150}$ This particular provision was deleted from the Basic Law: The Government (1992) passed one year later, but it reappeared in a 1996 amendment, ${ }^{151}$ and today appears as section 6 of the Government Law (2001), ${ }^{152}$ which was enacted together with the Basic Law: The Government of the same year. Section 6 of the Government Law states:

In the government there shall operate a Ministerial National Security Committee, comprising: the Prime Minister - Chair; Deputy Prime Minister if appointed, the Minister of Defence, the Minister of Justice, the Foreign Minister and the Internal Security Minister and the Minister of Finance; the government may, at the suggestion of the Prime Minister, add additional members to the committee, provided that the number of members in the committee not exceed one half of the members of the government. ${ }^{153}$

This provision implemented the recommendations of the Agranat Commission to establish a ministerial committee for security matters, with a limited number of members. ${ }^{154}$ However, prior to the establishment of a statutory committee, the government had already established the Ministerial National Security Committee under the power conferred by the 1992 Basic Law to appoint ministerial committees and to act by their agency.

Like other ministerial committees, decisions of the Ministerial National Security Committee are subject to a right of appeal given to every minister. If a minister appeals, the matter is submitted for the decision of the entire government. Unlike other ministerial committees, however, the Committee's decisions are not appended to the protocol of government decisions and are

150 S.H. 5751/1990-91, 125

151 S.H. 5756/1995-96, s. 39(A1)

152 S.H. 5761/2000-2001, 168

153 Ibid. [translated by author]. Moreover, section 7 provides that: "the government will have a team established and operated by the prime minister for permanent professional advice in the areas of national security."

154 Report of the Commission of Enquiry - The Yom Kippur War, supra note 134 at 25-26. consequently not sent to the ministers for their review. On the other hand, the ministers are entitled to examine the protocol of the Committee's decisions in the government secretariat, unless the prime minister orders otherwise. The decisions of the Committee are further shielded from broader review through the Government Rules of Procedure, which allow the government to submit a matter for decision by a ministerial committee. If the Committee makes a decision on the basis of such a referral, its decision would be final and need not be submitted for additional governmental deliberations. ${ }^{155}$

The government, as well as the Ministerial National Security Committee, occasionally empowers the prime minister, together with other ministers, including the minister of defence, to take operative military actions within the boundaries set by the government or the Committee. Moreover, since 1984, a mini-cabinet has been operating, known as "the kitchencabinet," which constitutes a permanent ministerial committee that enjoys the powers of the Ministerial National Security Committee. In this context, attention is drawn to the nature of the Israeli governmental structure. The Israeli system is a parliamentary one in which the government serves by virtue of the confidence of the Knesset, given to it as a collective body. The prime minister is not the commander of the armed forces of the state nor is the minister of defence. Rather, this authority is vested in the government in a collegial capacity. ${ }^{156}$ But obviously, by definition, the prime minister plays a central role in that constellation.

One could ask whether the Basic Law: The Army (1976) authorizes a body other than the government to initiate military actions. This question stems from sections $3(a)$ and (b) of this law, which state respectively that " $[\mathrm{t}]$ he supreme command level in the Army is the Chief of the General Staff" and that "[t]he Chief of the General Staff is . . subordinate to the Minister of

\footnotetext{
155 See "The status of a decision of a Ministerial Committee 'on behalf of the Government' is the same as a Government's decision," Guidelines of the Attorney General, vol. 2, no. 21.478 (15 February 85) (Hebrew). See also the opinion of the attorney general submitted to the minister of justice, D.K. 1966, vol. 46 at 1780-81. See generally Amnon Rubinstein \& Barak Medina, The Constitutional Law of the State of Israel, 5th ed., (Tel Aviv: Schocken, 1996) at 722-24 (Hebrew).

156 See Ben Meir, supra note 143 at 57.
} 
Defence." ${ }^{157}$ The question then arises as to whether these provisions confer independent status upon the chief of staff and the minister of defence. With respect to the chief of staff, the fact of his being " $[\mathrm{t}]$ he supreme command level in the Army" begs the question as to whether the minister of defence may give him operative instructions and whether the minister may give instructions directly to the army without going through the chief of staff. Despite the fact that these two questions are disputed, ${ }^{158}$ it appears that this Basic Law leaves no room to doubt the chief of staff's status as subordinate to the minister of defence and to the government.

Regarding the minister of defence, this Basic Law makes it clear that, irrespective of the scope of his powers $v i s-\grave{a}-v i s$ the chief of staff and the army, on the level of relations between himself and the government, he is no more than "the Minister in charge of the Army on behalf of the government." 159 Accordingly, it is clear that the government's decisions regarding the army are binding upon the minister. In this context, it bears mention that while the Basic Law states that the chief of staff is "subordinate to the Minister of Defence," according to the Hebrew version of the Basic Law, the chief of staff is still "subject to the marut [officially translated as "authority"] of the Government." As correctly noted by Ben Meir, "the Hebrew word for authority, marut, conveys a sense of absolute subjection." "160 Consequently, I do not think that the Basic Law purported to give the chief of staff or the minister of defence independent power to start military actions.

Obviously, the government may authorize the army to adopt military actions, within the framework of its duty to protect the security of the state. Such authorization may be explicit and may even

157 Basic Law: The Army (1976), supra note 133.

158 See "Constitutional Aspects of Relations Between the CabinetDefence Minister-Chief of Staff" in Compendium of Legal Opinions (Tel Aviv: Adjutant General's Office, 1980) vol. 40, legal opinion no. 10.0101 (Hebrew). This opinion is summarized in Ben Meir, supra note 148 at 56-75. See also Yehuda Ben Meir," Changes in the Relations between the Civil and Military Level in Recent Years" [unpublished manuscript]. For criticism of the vagueness of the Basic Law in determining the relationship between the minister of defence and the chief of staff and between the former and the government, see P. Elman, "Basic Law: The Army" (1977) 12 Israel Law Review 232 and Shetreet, supra note 135 at 33-36.

159 Basic Law: The Army, supra note 133, s. 2(b).

160 Ben Meir, supra note 133 at 57. be implied. Moreover, the authorization may flow naturally from the very nature of the army and its role. I have been unable to find any written document on this issue, and it is doubtful whether such a document indeed exists. In this area the army operates on the basis of practices that have developed over the years and to a large extent on the basis of common sense and the dictates of reality. Even so, to the best of my knowledge, there are internal IDF guidelines which delineate realms of responsibility and power within the army to decide upon urgent military measures in response to security threats. However, these documents are highly classified.

Nevertheless, there have been quite a few instances in the history of the State of Israel, both prior to the adoption of the Basic Law: The Army (1976) and thereafter, in which the minister of defence gave instructions to initiate military actions or to broaden military actions during the war, without the government's instructions, and even in defiance of its decisions. There have also been cases in which the minister of defence gained the cooperation of the chief of staff where the minister's policies were acceptable to him. ${ }^{161}$ To the extent that there were cases in which the minister of defence or the chief of staff acted in defiance of the government's directives, and not in the course of an urgent operation resulting from unexpected developments in the field, these officials would have acted in deviation from their legal authority. Furthermore, if the minister of defence or chief of staff acted in that manner without government directives, then it would seem that they also deviated from their authority in the political-strategic realm. In any event, a government decision may be adopted to prohibit the army from acting on the basis of conflicting orders from the minister of defence, pursuant either to the government's power as stipulated in section 2(a) of the Basic Law: The Army (1976) (under which the "Army is subject to the authority of the Government") or its residuary powers under section 32 of the Basic Law: The Government (2001). ${ }^{162}$

\footnotetext{
Ibid. at 59-61.

162 Dwikat v. Government of Israel, H.C.J. 390/79, 341 P.D. 1 at 10 (Hebrew) (abridged in 9 I.Y.H.R. 476, and in "Digest: Recent Legislation and Cases" 15 Israel Law Review 131).
} 
The possibility was raised that the minister of defence, who is aware of the fact that there is no governmental majority to start a war, could "direct the army to perform actions, not constituting acts of war as such, but intending that such acts should contribute to the deterioration into war." 163 It seems to me that such a directive is not within the power of the minister, even though it is not necessarily an initiation of war per se. It further seems that to a large extent such events are the result of the government ministers' inability to subject the actions of the minister of defence to professional scrutiny. In order to overcome this problem, the Ministerial Committee for National Security was established. At the same time, the National Security Council was constituted as an advisory body through an amendment in 1999 to the 1992 Basic Law. ${ }^{164}$

From its inception until today, the Council for National Security has been headed by senior military personnel and retired heads of the other security branches. The Council's existence is of tremendous importance in reduction of the government's exclusive reliance on the intelligence and security assessments of the army, and the creation of a coordinating organ between the military and the civilian authority as well as reducing the military influence on policymaking. ${ }^{165}$ It is for this reason that one may question the past appointment of a brigadiergeneral as head of the Council while he was on a leave of absence, but without retiring from the army. The cause for concern became even more apparent when this brigadier-general remained one of the forerunners for the position of chief of

163 Nun, supra note 6 at 124, footnote 156 [translated by author]. In this context, the claim was raised that during the Lebanese War, the minister of defence had given the IDF an order to broaden the military front, in defiance of the government's decision; see Ben Meir, supra note 133 at 59-60, 148-56.

164 The 1999 amendment, entitled "Prime Minister and Functioning of Government," added the following section to the Basic Law: The Government (1992): "The Government shall have a staff, established and operated by the Prime Minister, for permanent professional consultation in the realm of national security. The Prime Minister is entitled to charge the staff with additional areas of consultation." (S.H. 5756/1995-96, 30, s. $39(\mathrm{e}))$. This section was replaced by a similar one in the 2001 Basic Law. It was entitled "Advisory Staff for National Security" and was added to the Basic Law through the Government Law (2001), supra note 138, s. 7.

165 Yoram Peri, The Israeli Military and Israel's Palestinian Policy: From Oslo to the Al Aqsa Intifada (Washington, DC: United States Institute of Peace, 2002) at 52-57, online: United States Institutes of Peace <http://www.usip.org/pubs/ peaceworks/pwks47.html $>$. staff. ${ }^{166}$ The establishment of the Council was accompanied by high tension between the Council and the defence establishment. During the brigadier-general's term, tension also developed between the head of the Council and the prime minister, which adversely affected the Council's functioning.

It is difficult to delineate the precise boundaries governing the mutual relations between the prime minister, the minister of defence and the government in matters of security and the army, as well as their collective and individual relations with the chief of staff. Many of the arrangements in this area are rooted in conventions and customs ${ }^{167}$ and the personalities of the office-holders themselves are also an important variable. Even so, in view of the existing disputes, and having regard for the powers of the minister of defence and the army in matters concerning the initiation of military actions, it seems appropriate to consider explicitly applying the provision of section 40 (a) of the Basic Law: The Government (2001), such that the requirement for a governmental decision would be extended to the initiation of military operations as well. The amendment is essential in order to prevent the circumvention of the need for a government decision by initiating warlike operations that do not constitute a clear act of war. It also seems appropriate to consider making the provisions applicable to the conduct of war and the broadening or variation of its goals. ${ }^{168}$

Another important question is whether there is any restriction upon the power of the government

66 The Movement for Governmental Fairness v. The Prime Minister, H.C.J. 6777/00 [unpublished]. Initially, he was even supposed to stay in active service, not to wear military uniform and not participate in internal military deliberations. Only after this decision was challenged in court did the attorney general order him to take leave of absence. Not only might the appointment of an active officer to head the Council for National Security frustrate the aim of creating this body, it might have positioned him in a conflict between his subordination to the prime minister on the one hand, and to the chief of general staff on the other hand. The Supreme Court ruled, however, that the flexible wording of s. 39(e) of Basic Law: The Government enables the appointment of public servants to the Council.

167 Regarding the role of custom in this context, see D. Even, "Custom in Public Law - Following the Agranat Report" (1976) 7 Mishpatim 201 (Hebrew).

168 Eyal Nun, "The Constitutional Restrictions on the Army in Israel: A Proposal for Redrafting Basic Law: The Army" (2002) 16(A) Israel Defence Forces Law Review 161 at 183-84 (Hebrew) [Nun (2002)]. 
to start a war. To answer this question, I would suggest turning to the provisions of the Basic Law: The Army (1976), which states that "[t]he Defence Army of Israel is the army of the State." 169 Bendor and Kremnitzer have relied on this section to argue that "the name of the army Defence Army of Israel - expresses the concept that the role of the army in the area of the security of the state, is restricted to its defence." 170 Accordingly, the state can initiate war only where "the war is required for its defence" and the government is prevented from "initiating an aggressive war." $"$ This construction is also consistent with "the position of international law, which the state must respect, proscribing a war of aggression." 172 Regarding the authority to adopt military action, within the framework of subsection 40(b) of Basic Law: The Government (2001), these authors proposed that it "relates to military actions that are not on the scale of a war, and which constitute acts of defence in a battle begun by the enemy." 173

This argument is well grounded in Israeli law. The basic rule is that customary international law was incorporated into Israeli law and constitutes a binding source, unless it clearly contradicts a legislative act of the Knesset. Already four decades ago the Supreme Court wrote:

According to the law of Israel, which is identical on this point to English law, the relationship between municipal law and International Law is governed by the following rules:

(1) The principle in question is received into the municipal law and becomes a part of that law only after it has acquired general international recognition ....

169 Supra note 133 , s. 1

170 Bendor \& Kremnitzer, supra note 114 at 37 [translated by author].

171 Ibid. Justice Haim Cohn proposed the replacement of s. 40 of the Basic Law with an explicit provision prohibiting the initiating of aggressive wars. See Haim H. Cohn, "Remarks to the Proposal for Israeli Constitution" (1999) 5 Mishpat Umimshal 49 at 56 (Hebrew).

172 Bendor \& Kremnitzer, ibid.

173 Ibid.
(2) This, however, only applies where no conflict exists between the provisions of municipal statutory law and a rule of International Law. But where such a conflict does exist, it is the duty of the Court to give preference to and apply the laws of the local Legislature .... True, the presumption must be that the Legislature strives to adjust its laws to the principles of International Law, which have received general recognition. But where a contrary intention clearly emerges from the statute itself, that presumption loses its force and the Court is directed to disregard it.

(3) On the other hand, having regard for the above-mentioned presumption, a local statutory provision that is equivocal, and whose content does not demand a different construction, must be construed in accordance with the rules of public International Law. ${ }^{174}$

The prohibition of the use of inter-state force proscribed by the Charter of the United Nations ${ }^{175}$ presents "the cornerstone of present-day customary international law." ${ }^{176}$ Moreover, the interpretive rule endeavoring to adjust principles of international law with municipal norms has been extended to apply also to conventional international law. Thus, the rule has been stated in general terms as follows:

174 Eichmann v. A.G, Cr.A.336/61, 16 P.D. 2033 at 2040 (Hebrew) [translated by author], 36 I.L.R. 277 at 280-81. See also Amsterdam v. Minister of Finance, H.C.J. 279/51, 6 P.D. 945 at 966 (Hebrew), 19 I.L.R. 229 at 233; Anonymous v. Minister of Defence, Cr.F.H 7048/97, 54 P.D. 721 at 742-43 (Hebrew); Sheinbein v. A.G., Cr.A. 6182/98, 53 P.D. 625 (Hebrew); Yated Ass. v. Ministry of Education, H.C.J. 2599/00, 56(5) P.D. 834 at 846 (Hebrew); Ruth Lapidoth, "International Law within the Israeli Legal System" (1990) 24 Israel Law Review 451; Yoram Dinstein, International Law and the State (Tel Aviv: Schoken, 1971 ) at 143-48 (Hebrew); and Aharon Barak, Interpretation in Law Statutory Interpretation (Jerusalem: Nevo, 1993) vol. 2 at 575-78 (Hebrew).

175 Supra note 99, Art. 2(4).

176 Dinstein, War, Aggression, and Self-Defense, supra note 38 at 90. See also Krzysztof J. Skubiszewski, "Use of Force by States, Collective Security, Law of War and Neutrality" in Manual of Public International Law (London: McMillan, Max Sorensen ed., 1968) 739 at 745 
The court would interpret the written laws of Israel in such as would prevent, as far as possible, conflict between internal law and the recognized principles of international law, so that the internal law of Israel would be compatible with the obligations of the State according to international law. Only when there was a contradiction between the internal law and international law must the Court prefer its internal law. ${ }^{177}$

It is submitted that there is no conflict between the provisions of existing municipal legislation and the rule of international law regarding the initiation of a war. The proscription in international law of using force in the solving of international disputes is consistent with the language of Basic Law: The Army (1976). This interpretation also accords with the language of section 18 of the Law and Administration Ordinance 1948, which states that the armed forces of the state are permitted "to do all legal actions that are necessary for the protection of the state." 178 Supreme Court Justice Itzhak Zamir wrote that this section remains "the principal source of military power" today. ${ }^{179}$

In this regard it is appropriate to recall the Supreme Court's statement regarding articles 33, 37, and 38 of the UN Charter:

Israel [is a] member of the United Nations and [is] bound to conduct [itself] in accordance with the articles of the Charter .... State Members of the United Nations cannot be in a state of war until at least they have made some effort to reach agreement with their enemy or

177 Kamiar v. The State of Israel, Cr. A. 131/67, 22:2 P.D. 85 at 112 (Hebrew), 44 I.L.R. 197 at 203, Landau J. In recent Israeli literature, the distinction between customary and conventional law has been challenged on principles of international law, especially in the areas of human rights, security and foreign relations. See e.g., Barak, supra note 174, vol. 3 at 237; Eyal Benvenisti, "The Implications of Considerations of Security and Foreign-Relations on the Application of Treaties in Israeli Law (1992) 21 Mishpatim 221 (Hebrew); Yaffa Zilbershatz, "The Role of International Law in Israeli Constitutional Law” (1997) 4 Mishpat Umimshal 47 (Hebrew); and Daphne Barak-Erez, "The International Law of Human Rights and Constitutional Law: A Case Study of an Expanding Dialogue" (2004) 2 International Journal of Constitutional Law 611.

178 Supra note 111.

179 Zamir, supra note 128 at 235 [translated by author]. while the Security Council has not yet reached a decision concerning the state of affairs which has come into existence between the two States. ${ }^{180}$

The question, then, is: Who is to supervise the government to ensure that it does not deviate from its mandate to engage in defensive wars, by the initiation of a "war of aggression"?

Though the Supreme Court is a pioneer in the realm of intervention with the decisions of the executive branch, ${ }^{181}$ the dimension of initiating wars has remained within the scope of the classical realm in which the court will not intervene. It was immediately following the establishment of the State of Israel that the Court ruled that "[t]he declaration of war and the decision that a state of war still exists are matters for the exclusive discretion of the executive authority." 182 In relating to the Knesset's authority to deal with foreign relations and state security, the Supreme Court recently ruled:

[T] he power of the competent authority (the government) and the nature of the matter (foreign relations and security) allow the government a wide range of discretion in this kind of matter. Within the boundaries of that range, the court will not substitute the government's discretion with its own. The Knesset is charged with the supervision of the exercise of government powers in these matters.... One government has a certain policy ... another one adopts a different policy. Both of them are within the government's discretion. It is for the government to choose between policies and supervision thereof is the classic role of the Knesset. ${ }^{183}$

so Jiday, supra note 39 at 699-700

81 Asher Maoz, "Justiciability" [unpublished manuscript].

182 Zilbrechot v. A.G., Cr.A.(T.A.) $303 / 52,9$ P.D. 75 at 83 (Hebrew).

183 Weiss, supra note 145 at 471-72, President Barak [translated by author]. Justice Zamir, who concurred with Barak J.'s decision to reject the petition, regarded the issue as being non-justiciable (ibid. at 480). The petition was directed against the negotiations towards a peace agreement, between the Israeli government and the Palestinian Authority, following the resignation of the government. See Asher Maoz, "War and Peace in the Supreme Court" [unpublished manuscript]. 
In this respect, it is significant that section 40 (c) of the Basic Law: The Government (2001) imposes a duty on the government to notify the Foreign Relations and Security Committee of the Knesset of its decision to begin a war, and even of army actions that do not fall within the definition of war. Particular importance attaches to the prime minister's duty to give the Knesset notice of a government decision to start a war. This was an important innovation. Prior to the introduction of section 40 (c), the standard practice was for the prime minister, the minister of defence, and the chief of staff to report to the Foreign Relations and Security Committee of the Knesset regarding military activities, post facto. Further, a convention developed by which the prime minister would inform the leaders of the opposition of anticipated military activities. ${ }^{184}$ Nevertheless, there was no duty to report the beginning of a war to the Knesset plenum. Even though Prime Minister Menachem Begin updated the leaders of the Labor Party in opposition of the invasion of Lebanon, in 1982, he did not give notice to the Knesset. ${ }^{185}$ Hence, section 40 (c) was the first instance of the duty to report being statutorily anchored in a Basic Law. Clearly this represented an attempt to increase Knesset involvement and supervision in this particularly sensitive area.

It should be noted, however, that section 40 (c) only establishes a duty of notification, and does not make the government's decision contingent upon Knesset approval. ${ }^{186}$ Furthermore, the government has interpreted section 40 narrowly. For example, the provision requiring that notice of military actions be given to the Foreign Relations and Security Committee came into effect in 1996 but has been utilized on only one occasion. This was following the government's decision to initiate the "Defensive Shield" operation. The decision was adopted at the end of March 2002, following a series of terrorist attacks against Israel that climaxed in a suicide attack perpetrated in a

184 See Shetreet, supra note 135 at 37.

185 Ultimately, the Knesset gave its indirect approval to the initiation of the war two days after it began. This occurred when the no-confidence motion, submitted by the Communist faction of the Knesset, was rejected. See Ben Meir, supra note 143 at 42-45.

186 It might be interesting to compare these provisions with the situation in Canada, both the formal and the real; see Ikechi Mgbeoji, "Reluctant Warrior, Enthusiastic Peacekeeper: Domestic Legal Regulation of Canadian Participation in Armed Conflicts" (2005) 14:2 Constitutional Forum constitutionnel 7.
Netanya hotel on Passover Eve. Twenty-nine people were killed and 140 people were injured in the attack during the religious ceremony of the Seder. In its wake, the government decided to initiate a comprehensive military operation against the terrorist infrastructure in the West Bank. The operation included entry into cities controlled by the Palestinian Authority and military actions against the terrorist organizations. From this incident, it is apparent that the government interprets its duty under section 40(b), which is to give notice to the Foreign Relations and Security Committee, as applying exclusively to large-scale operations.

Apparently, the Knesset's effective power to oppose a decision to go to war or to engage in other military activities is limited to its normal modes of supervision over government activities. ${ }^{187}$ Thus, the Knesset plenum can convene a session following a motion for the agenda submitted by one of its members, or the deliberation may be moved to the Foreign Affairs Committee if a debate thereon in the Knesset plenum is liable to harm the security of the State or its foreign relations. ${ }^{188}$ Knesset members may likewise present questions to the minister of defence, or to the prime minister, following a military action. ${ }^{189}$ The relevant Knesset committees can discuss the pertinent topics. They may demand explanations and information from the relevant ministers, as well as demand that a particular minister or his representative appear

\footnotetext{
187 Maoz, supra note 2 at 16-17.

188 See Knesset Rules of Procedure, Part B, ch. 5, online: Knesset $<$ http://www.knesset.gov.il/rules/eng/contents.htm $>$.

189 Ibid., Part B, ch. 3.
} 
before the committee in that respect. ${ }^{190}$ The Knesset may even establish a parliamentary committee of enquiry to investigate particular actions. ${ }^{191}$ Finally, the Knesset may express its lack of confidence in the government and cause its resignation. ${ }^{192}$ Still, the Knesset cannot instruct the government with respect to how to act. ${ }^{193}$ The Knesset can, however, control the government's decisions by way of the Budget Law, which is within its discretion. ${ }^{194}$ It can also exploit its control over the enlistment of reserve soldiers during times of emergency. ${ }^{195}$

190 Ibid, ch. 6. Section 42 of the 2001 Basic Law, supra note 138 , sets out the following:

(a) The Government will provide the Knesset and its committees with information upon request and will assist them in the discharging of their roles; special provisions will be prescribed by law for the classification of information when the same is required for the protection of state security and foreign relations or international trade connections or the protection of a legally mandated privilege. (b) The Knesset may, at the request of at least forty of its members, conduct a session with the participation of the Prime Minister, pertaining to a topic decided upon; requests as stated may be submitted no more than once a month.

(c) The Knesset may obligate a Minister to appear before it, similar authority is granted to any of the Knesset committees within the framework of their tasks. (d) Any of the Knesset committees may within the framework of the discharging of their duties, and under the auspices of the relevant Minister and with his knowledge, require a civil servant or any other person prescribed in the law, to appear before them

(e) Any Minister may speak before the Knesset and its committees.

(f) Details regarding the implementation of this section may be prescribed by law or in the Knesset articles.

191 Knesset Rules of Procedure, ibid., ch. 5 at 1.

192 See Basic Law: The Government (2001), supra note 138, s. 28.

193 See legal opinion of the Attorney General, "Government's failure to respond to a matter regarding which a proposal to protocol was submitted" Guidelines of the Attorney General, vol. B, no. 21.460 (1 May 1970) (Hebrew). See also Yoram Dantziger, "Towards Reinforcing the Status of the Knesset's Decisions" (1981-1982) 34 HaPraklit Part 1 at 212, Part 2 at 413 (Hebrew)

194 See s. 3(a)(1) of Basic Law: The State Economy: "The State Budget shall be prescribed by Law." An unofficial English translation of this Basic Law can be found online: Knesset, The Basic Laws: Full Texts <ttp://www.knesset.gov.il /description/eng/eng_mimshal_yesod 1.htm $>$.

195 Section 34 of the Defence Service Law 1986 (Consolidated Version) authorizes the minister of defence, "if the security of the State so requires ... to call upon any person of military age who belongs to the reserve forces of the Israel Defence Forces, by order to report for regular service or reserve service, as specified in the order, at the place and time prescribed therein, and to serve as long as the order is in force" (L.S.I. 5746/1986, vol. 40 at 112). Such an order must, "as soon a possible" be brought to the notice of the Foreign Affairs and Security Committee of the Knesset, which may confirm it or refrain from confirming it. Furthermore, the minister's order will expire
One final area of parliamentary supervision over government powers to make and declare war is found in the rules regarding the declaration of a state of emergency. The 1992 Basic Law introduced a revolution regarding these rules. Section 9(a) of the Law and Administration Ordinance 1948 empowered the ministers to enact regulations for times of emergency. These regulations expired three months after their enactment, unless the Knesset extended their validity. This power was dependent upon the Knesset having actually declared that a state of emergency exists in the country. Such a declaration was made a few days after the establishment of the State of Israel and has not since been revoked, nor has the Knesset ever seriously discussed the need for its continued existence. ${ }^{196}$ The 1992 Basic Law introduced a new mechanism that now finds expression in sections 38-39 of the Basic Law: The Government (2001). Under this mechanism, the Knesset cannot declare the existence of a state of emergency unless it has first ascertained that "the State is in a state of emergency." "197 This declaration is valid for a period of one year, and it must be renewed annually. ${ }^{198}$ Once a state of emergency has been declared, the government is empowered "[to] make emergency regulations for the defence of the State, public security and the maintenance of supplies and essential services." 199 The power to enact emergency regulations is conditional upon the fact that their establishment be "warranted by the state of emergency." ${ }^{200}$ The government must submit these regulations to the Foreign Relations and Security Committee of the Knesset at the first opportunity presenting itself after their promulgation. The regulations will expire at the

within fourteen days unless confirmed by the Committee or the Knesset plenum.

196 A petition is currently pending in the Supreme Court, requesting a determination that the Knesset declaration on the existence of a state of emergency has expired, based on the claim that it no longer has an appropriate factual basis and is therefore unreasonable. See The Israel Association of Citizens Rights v. The Knesset (1999), H.C.J. 3091/99.

197 Supra note 138, s. 38(a).

198 Even so, the government is empowered to declare the existence of a state of emergency if it has ascertained the existence of an emergency situation that dictates such a declaration and there is no possibility of convening the Knesset. The validity of the declaration will expire within seven days, unless approved by the Knesset. Absent the possibility of convening the Knesset, the government may issue a repeat declaration of the existence of an emergency situation.

199 Supra note 138, s. 39(a)

200 Ibid., s. 39(e). 
end of three months unless extended by statute, or by a decision of a majority of the Knesset members.

The declaration of a state of emergency is not a precondition for exercising the authority to start a war or for the adoption of "military actions necessary for the defence of the state and public security." ${ }^{201}$ Even so, the tight supervisory power of the Knesset in a time of emergency may affect the conduct of the government in this area as well.

Summing up our discussion of parliamentary supervision over the government in the matters of initiating war or other military operations, it is important to once again stress that the Israeli regime is a parliamentary one. As such, the government rules by virtue of the confidence of the Knesset. Given that the factions comprising the government necessarily include a majority of the Knesset members, the government should prima facie have no problem obtaining a majority in the Knesset or in the Foreign Relations and Security Committee in support of its policy. However, such support cannot be taken for granted. For example, the defence minister's request from the Foreign Relations and Security Committee to approve enlistment orders for reserve soldiers prior to the Defensive Shield Operation was initially rejected by the Committee and only approved after an additional session.

\section{D) Future Developments}

The current legal position regarding civilian supervision of military decisions to engage in military actions is not free from defects. This has led to a number of initiatives for a reassessment of the position and legislative amendments being put forward.

In September 2003, the Knesset Speaker and chairman of the Foreign Affairs and Defence Committee appointed a public committee, headed by Professor Amnon Rubinstein, to examine the parliamentary supervision of the defence establishment and the methods for improving it (the Rubinstein Committee). The Rubinstein Committee submitted its conclusions and

201 Ibid., s. 40(b). recommendations in December 2004. ${ }^{202}$ In its report, the Committee pointed out the inherent contradiction of parliamentary supervision over the army and the secret services. On the one hand, security matters are existential in a country like Israel, therefore tight supervision of the Knesset, as the representative of the people, is essential. On the other hand, by their very nature, these issues must be kept secret.

The compromise advocated by the Rubinstein Committee was to entrust the supervision to the Foreign Affairs and Security Committee, whose deliberations are concealed from the media. The Committee recommended that the Foreign Affairs and Security Committee carry out full-scale supervision over the security institutions, "as applied by parliament over any other activity of the executive branch." Moreover, the Committee recommended that "subject to the rule that requires protection of secrets whose revealing might directly endanger the security of the State, the principle to be adopted is that the more the deliberations are open, the better it is both for Israel's democracy and to its security." The Committee further recommended that although the Foreign Affairs and Security Committee should have no commanding authority over security institutions, it should be able to present its findings directly to the prime minister and to the minister of defence for their consideration. This is of major importance since "in the emergency regime of Israel often decisions in security matters have wide strategic, political and economical applications."

The Rubinstein Committee emphasized the role of the Foreign Affairs and Security Committee in ensuring that full governmental supervision over security institutions is being carried out. It pointed out that while Basic Law: The Government provides for the establishment of a Ministerial National Security Committee and an advisory staff for national security, ${ }^{203}$ the Basic Law refrains from stating their authority. This leaves the prime minister with sole discretion regarding what issues should be brought to the ministerial committee for approval. The

\footnotetext{
202 See online: The Knesset: The Israeli Parliament $<$ http://www.knesset.gov.il/committees/heb/docs/confidence. pdf $>$ at 43 (Hebrew).

203 Supra note 152.
} 
Committee recommended that the government promulgate, and bring to the notice of the Foreign Affairs and Security Committee, detailed regulations as to the authority of the ministerial committee as well as define military actions that require prior approval by the committee.

In order to be able to carry out its supervisory duties, the Foreign Affairs Committee, or one of its subcommittees, should receive all relevant information and be able to summon any personnel of the security bodies. While being clear on the duty to report past operations, the Rubinstein Committee was less equivocal about the duty to disclose planned operations. The Committee stated that the more the Foreign Affairs and Security Committee will be involved in supervising the process of adopting decisions by the security echelon, the less chances for achieving wrong decisions. It distinguished between routine operations that should be left to the exclusive supervision of the government and operations that have strategic implications over the Israel's status, its international relations and the risk of war breaking out. Yet, the Rubinstein Committee left it up to the prime minister to decide whether to consult about such operations with parliament and whom to consult with - members of the relevant subcommittee of the Foreign Affairs and Security Committee, the opposition leader or chairs of parliamentary factions. The Committee stated: "It seems to us that in extreme circumstances of decisions that may bear existential significance, it is proper to hold such deliberations, according to the prime minister's discretion." 204

The Foreign Affairs and Security Committee adopted the recommendations of the Rubinstein Committee and incorporated them in a statement of "the purpose, structure, missions and working principles of the committee." 205

On 28 March 2004, the Subcommittee for Intelligence and Secret Services of the Foreign

Supra note 202 at 57 [translated by author].

205 See online: The Knesset: The Israeli Parliament $<$ http://www.knesset.gov.il/committees/heb/docs/confidence pdf $>$ at 3 . The Committee also submitted bills to carry out some of the Rubinstein's Committee recommendations. See e.g., Bill, Knesset Law (Amendment 21) (Summon of the Chief of Staff to the Foreign Affairs and Security Committee), Hatsaot Hok 5765/2005 at 107(Hebrew), online: The Knesset: The Israel Parliament $<$ http://www.knesset.gov.il/Laws/Data/BillKnesset/ 70/70.pdf $>$.
Affairs and Defence Committee of the Knesset, sitting as the Committee to Investigate the Intelligence Community Following the $\mathrm{W}$ ar in Iraq, presented its public report. ${ }^{206}$ In its report, the Committee criticized the intelligence agencies for making assessments on Iraq's non-conventional capabilities that was based on speculation rather than reliable information and its failure to make an accurate assessment of Libya's chemical and nuclear programs. The Committee made recommendations for the improvement of the control of the political echelon over the intelligence services. These included establishing the headquarters for intelligence matters at the prime minister's office that would be headed by a civilian and would assist the prime minister in directing and supervising the intelligence services. The Committee recommended, moreover, the establishment of a Ministerial Committee for Intelligence Matters. The Committee made further recommendations for major reforms of the intelligence community, recommending that intelligence assessment be concentrated at the prime minister's intelligence headquarters and the Ministerial Committee for Intelligence Matters. It also recommended a national assessment to be submitted annually to the National Security Council, to the prime minister and to the Ministerial Committee for Intelligence Matters.

Recently, the prime minister's office, upon the initiative of the National Security Council, distributed a memorandum for an amendment to the Government Law, entitled Government Law (National Security Council) (Amendment) $5764 / 2004 .{ }^{207}$ This provides a legal basis for the activities of the National Security Council, the pertinent provisions regarding it having been deleted from the Basic Law: The Government (2001). The proposal purports to replace section 7 of the Government Law. The amendment provides as follows:

\footnotetext{
6 Online: The Knesset: The Israeli Parliament $<$ http://www. knesset.gov.il/docs/heb/intelligence_irak_report.pdf $>$ (Hebrew). An English translation of this report can be found on the Knesset homepage. See Knesset Foreign Affairs and Defence Committee: Report on the Committee of Enquiry into the Intelligence System in Light of the War in Iraq (March 2004), online: The Knesset <http://www.knesset.gov.il/committess/ eng/docs/intelligence_complete.pdf $>$.

207 Law Memorandum: Government Law (National Security Council) (Amendment) 5764/2004, File 23741-15 (Hebrew).
} 
7. (a) Alongside the Government there shall function a National Security Council which will serve as a coordinating staff for the Prime Minister and the Government in the areas of national security of the State of Israel.

(b) The National Security Council shall be appointed by the Government in accordance with the proposal of the Prime Minister.

(c) 1.The National Security Advisor shall be appointed by the Government in accordance with the proposal of the Prime Minister. ...

(d) These are the duties of the National Security Advisor:

1. To maintain a senior advisory forum for the Prime Minister, the Government and its committees in the realm of the national security of the State of Israel.

2. To maintain a coordinating staff in cooperation with the Government Ministries and bodies dealing with national security, to coordinate and formulate integrated assessments of processes and trends relating to the areas of national security.

3. To coordinate and prepare, according to the guidelines given by the Prime Minister, the groundwork for deliberations of the Government and its committees.

4. To monitor the execution of the government decisions in the realm of national security, according to the guidelines of the Government or the Prime Minister.
5. To make recommendations to the Prime Minister in the realms of national security, and, subject to his guidelines, t o p re se $\mathrm{t} \quad \mathrm{th}$ e recommendations to the Government.

6. To formulate, with the assistance of other relevant national entities, long range programs concerning national security.

7. To maintain a coordinating staff in the area of the struggle against terror, and to recommend policy in that area.

(e) The Prime Minister will utilize the National Security Council, guide it and may charge it with additional tasks in the realm of national security.

(f) Nothing in the provisions of this section shall derogate from the power given to any other person, under any law, in matters dealt with in this section.

In the explanatory note to the memorandum, it is clarified that it is an attempt "to achieve conformity between the law and the government decision of 1999, which established the National Security Council." ${ }^{208}$ The explanatory note further clarifies that the existing section 7 does not conform to the government's 1999 decision, to the extent that it "assigns the Council a role of professional consultation only, whereas the government decision established additional roles." ${ }^{209}$ As the explanatory note states:

The proposed law expands the roles of the National Security Council beyond the provision of permanent consultation in the areas of national security. It establishes the duties of the Council in conformity with the foregoing

208 Ibid. [translated by author].

209 Ibid. 
government decision. In addition to its advisory role, the Council will also issue assessments and recommendations in the area of national security, increase the coordination between the government offices in matters of national security, will monitor the execution of government decisions in that area, plan the components of national security with a long term perspective, and promote connections and coordination with parallel bodies in selected states. ${ }^{210}$

Finally, the explanatory note also makes it clear that " $[\mathrm{t}]$ he Prime Minister will utilize the National Security Council, guide it and will be entitled to give it additional tasks in the area of national security, above and beyond the tasks enumerated in the proposed law." 211 In the meantime, a new national security advisor had been appointed and, upon his request, the prime minister's office has withheld furthering the legislative initiative until the advisor has had the chance to study the matter.

Another initiative is the draft of a comprehensive "Consensual Constitution" currently being prepared by the Knesset Constitution, Law, and Justice Committee. The current draft will incorporate the existing Basic Laws with changes after being revised, and it will also introduce constitutional chapters that have not yet been enacted as Basic Laws. The Committee has conducted a number of sittings that dealt with the army and its relations with the civilian powers, as well as the determination of powers to take military actions. The Committee was presented with the proposal to replace the current Basic Law: The Army (1976) and section 40 of the Basic Law: The Government (2001). A proposal was even made to incorporate the Basic Law: The Army into the Basic Law: The Government.
Alternatively, changes were proposed to the wording of the Basic Law: The Army. ${ }^{212}$

Alongside official reform initiatives, there were several private proposals to reform the present situation. In 1983, a think-tank comprised of reserve generals, professors of law and political scientists, jurists, and public figures, presented its proposal to the Knesset Subcommittee for Basic Laws. ${ }^{213}$ Parts of the proposal are obsolete in view of legislative changes that have since taken place. Other parts of the document remain worthy of consideration. The team proposed enacting The Authorization of Military Operations and Obligations Law. The proposed bill provides for the procedures of initiating military actions and obligations and for parliamentary supervision thereof. The division of powers within the government regarding military actions is also detailed. Section 1 provides for: embarking on an initiated war and determining its aims; laying down a war plan and any fundamental alterations to it; certain operations during peace time, such as an operation undertaken by a brigade of the armed forces; prolonged shelling; the operation of fighter planes; the advance of army forces during a war beyond the ceasefire line; and the emergency mobilization of the reserve forces. All of these actions require prior authorization by the government plenum. Section 2(a) provides for the establishment of a Cabinet Committee on Security Matters, composed of no more than a third of the government. This committee would have the power to authorize more limited military operations and would be required to approve actions initiated by the army during peacetime for purposes other than reconnaissance or intelligence, initiated shelling, and the operation of fighter planes beyond the state border. In cases where circumstances demand urgent action, the prime minister, in consultation with government ministers, including the defence and foreign ministers, would be empowered to take action and

\footnotetext{
212 See online: The Knesset: The Israeli Parliament $<$ http://www.knesset.gov.il/huka/FollowUpLaw_2.asp > (Hebrew). These drafts took notice of legislative proposals made by Nun (2002), supra note 168 at 176-99. These proposals are presented in the appendix to this article. Alongside the Knesset initiative, draft constitutional changes have been submitted by unofficial bodies and individuals. The most recent is the draft presented by the Israel Democracy Institute, online: <http://www.idi.org.il/hebrew/article.asp?id= 2351>.

213 See Shetreet, supra note 135 at $42-45$.
} 
receive government approval after the fact. This expedited procedure would not apply, however, to the initiation of war and defining its objectives.

The proposed bill obliges the prime minister and the defence minister to report to the Foreign Affairs and Defence Committee on the actions of the army and related political steps within ninetysix hours of their being summoned. It also divides military operations and obligations into different categories with different procedures for authorization. Any political-military obligation, or obligations to another state to put military forces into action, would require prior authorization by the Knesset plenum. Treaties, however, may be approved by the Foreign Affairs and Defence Committee since their public discussion might harm state security. Actions undertaken against a state which is neither an enemy nor bordering with Israel would require prior authorization by a subcommittee of the Foreign Affairs and Defence Committee. Actions that are within the authority of the government and the Cabinet Committee on Security Matters must be brought before the Foreign Affairs and Defence Committee for post factum approval.

The bill imposes the duty upon the government to establish rules for the procedure of authorizing military operations that are not provided for by the law. The goal, as stated by the chair of the team, was "to ensure that all military operations would require authorization according to a particular procedure. $" 214$

\section{ARMED CONFLICTS SHORT OF WAR}

The confrontation between the Palestinians and the State of Israel, which has been going on since September 2000, gave rise to a plethora of petitions to the Supreme Court, sitting as the High Court of Justice. All of these petitions deal with the manner in which Israel was conducting the war. In this context, it should be noted that the Israeli Supreme Court hears petitions filed by residents of occupied territories, a phenomenon without precedent in international law. ${ }^{215}$ The Supreme Court has also intervened in military actions when persuaded that human rights have been infringed. ${ }^{216} \mathrm{~A}$ great number of petitions were presented to the Supreme Court following the IDF operations during the recent uprising in the territories, both by civil right groups and by individuals from Israel and from the territories. ${ }^{217}$

A petition is currently pending against the Israeli government, the prime minister, the minister of defence, the IDF, and the chief of staff, urging them to refrain from the actions of "targeted killing." 218 To provide some context, the IDF undertakes targeted killing of terrorists and their senders, who are located in the areas controlled by the Palestinian Authority, in order to thwart their terrorist actions. Israel claimed that targeted preemptive killings are performed as "an exceptional measure, when there is urgent and definite military need, and only when there is no other, less severe, alternative." ${ }^{219}$ The rule was that "where there are other realistic alternatives, for example detention, then these alternatives should be implemented, even though it occasionally

215 See Amnesty International Report 1984 (London: Amnesty International Publications, 1984) at 35; Maoz, supra note 2 at 824 and references at notes 64-65; Asher Maoz, "Constitutional Law" in Ariel Rosen-Zvi, ed., Yearbook on Israeli Law 1991 (Tel Aviv: Israel Bar, Tel Aviv District, 1992) 68 at 98-103; and Asher Maoz, "Constitutional Law" in Ariel Rosen-Zvi, ed., Yearbook on Israeli Law 1992-1993 (Tel Aviv: Israel Bar, Tel Aviv District, 1994) 143 at 192-95.

216 See Barak-Erez, supra note 173 at 618.

217 For a sample of those petitions, see: Physicians for Human Rights v. O.C. Southern Command, H.C.J. 8990/02; FishLifschitz v. A.G., H.C.J. 10223/02; Yassin v. Commander of Kziot Military Camp, H.C.J. 5591/02; Center for Defense of the Individual v. IDF Commander, H.C.J. 3278/02; Ajuri v. IDF Commander, H.C.J. 7015/02; Almandi v. Minister of Defence, H.C.J. 3451/02, 56:3 P.D. 30[Almandi]; Physicians for Human Rights v. The Commander of the IDF Forces in the West Bank, H.C.J. 2117/02; Barake v. Minister of Defence, H.C.J. 3114/02; Physicians For Human Rights v. The Commander of IDF, H.C.J. 2936/02; and Center for the Defence of the Individual $v$. Minister of Defence, H.C.J. 3117/02. An English translation of these Court opinions is available from the official site of the Supreme Court, online: State of Israel, Judicial Authority $<$ http://62.90.71.124/eng/ verdict/framesetSrch.html $>$.

218 Public Committee Against Torture v. Government of Israel, H.C.J. 769/02 (Petition for an Order Nisi and an Interim Order) (Hebrew) [Public Committee Against Torture].

219 Public Committee Against Torture, ibid. (Supplementary Notification of the State Attorney's Office) (Hebrew) [Supplementary Notification, translated by author]. Regarding targeted killings, see J. Nicholas Kendall, "Recent Developments: Israeli Counter Terrorism: 'Targeted Killings' under International Law" (2001-2002) 80 North Carolina Law Review 1069, and S.R. David, "Fatal Choices: Israel's Policy of Targeted Killing" (2002) 51 Journal of Mideast Security and Policy Studies 14

214 Ibid. at 44. 
involves substantially endangering the lives of soldiers. ${ }^{, 220}$ A central dispute between the parties relates to the legal rubric of Israel's actions, which naturally has a bearing on their legality.

In its session on 18 April 2002, the Court instructed the respondents to present their position on the following three questions, pertaining to the petition:

(a) According to the legal categorization acceptable to them, which set of laws is applicable to the issue before us: Laws of War, Armed Conflict Short of War, or another classification?

(b) What are the rules of "internal" Israeli law applicable in our case (if indeed there are such)? Which rules of international law applicable in Israel apply to our case? What are the contents of these rules in relation to the matter being petitioned? What is the criterion for distinguishing between permitted and prohibited actions?

(c) What is the relationship between the "internal" Israeli law and the international law relevant to this case? Are these two sets of laws commensurate with each other? $?^{221}$

While the petitioners claimed that the relevant law is the Israeli criminal law, the state attorney claimed that the relevant law for this matter is customary international law of war. ${ }^{222}$

220 Supplementary Notification, ibid.

221 Public Committee Against Torture, supra note 218. The Court's decision from 18 April 2002 is available online: State of Israel Judicial Authority <http://elyon2.court.gov.il/files/02/690/007/ A 04/2007690.A04.pdf $>$ [translated by author].

222 Even so, the state attorney's office claimed that "even if actions were performed in accordance with the laws of war, at time of actual fighting, they must be examined in accordance with the specific provisos of the criminal law, the conclusions would not change ... The provisions of the criminal law create an explicit qualification of criminal liability where the action was performed under legal authority" (Supplementary Notification, supra note 219). This provision appears in s. 34(1) of the Criminal Law, which states that "[a] person is not criminally responsible for an act performed in accordance with one of the following: (1) he was bound or authorized by law to do it."
The response of the state attorney dealt primarily with ius in bellum and not with ius ad bella and the latter is thus not relevant for this article. For our purposes, what is important is the method utilized by the state attorney to reach the conclusion that the relevant classification is the law of war. The state attorney noted:

[I]n the wake of the events which began at the beginning of September $2000 \ldots$ the State of Israel was required to define the new situation that had emerged in the Areas in general, and specifically in relation to the Palestinian Authority. Having assessed all of the pertinent aspects, the State determined that the appropriate legal appellation for the situation was an "Armed Conflict Short of War." 223

The state attorney then reviewed the events since September 2000, noting the terrorist nature of the attacks in terms of the methods used (firing attacks, suicide bombings, firing of missiles, rockets, exploding cars) and the civilian and military targets (civilian centers, shopping malls, markets, buses, army bases and installations of the security forces). After discussing the relationship of the Palestinian Authority and the organizations perpetrating these attacks, noting in particular the failure of the Palestinian Authority to prevent them or act against the perpetrators, the state attorney moved on to discuss the measures taken by Israel against these attacks:

In responding to this wave of terror, the State of Israel has adopted a broad series of security measures, of various levels of severity. These have included inter alia, intensified security preparedness, detention of wanted persons, policies of restricting and supervision of movement, initiated operations in all territories of Judea, Samaria and Gaza, including the "A"

Supplementary Notification, ibid. at para. 13. See also Orna Ben-Naftali \& Keren R. Michaeli, “We Must Not Make a Scarecrow of the Law': A Legal Analysis of the Israeli Policy of Targeted Killings" (2001) 36 Cornell International Law Journal 233. They state that "[i]t is . . safe to conclude that the conflict is more than a mere 'unorganized insurrections, or terrorist activities' and is a full-scale 'armed conflict,' even under the harshest of term s" (at 258-59). 
zone air strikes, etc. Within the framework of these actions, the State of Israel has used most of its ordnance, including tanks and armored vehicles, fighter jets and helicopters, missiles, special units, etc. The dimensions of the combat and its special characteristics have forced the state over time to enlist reserve forces, immediately, by way of special enlistment orders. ${ }^{224}$

The state attorney thus summarized: "This situation is one in which 'substantial acts of combat' are occurring in the territories." 225

The state attorney continued its argument by noting that " $[\mathrm{t}]$ his position has been presented in the past and is still presented by the State of Israel in various forums, "226 referring to the first position paper that was presented by the State of Israel to the Mitchell Committee (The Sharm El-Sheikh Fact Finding Committee), which was established following the Sharm El-Sheikh Agreement of October 2000. There, Israel stated that:

Israel is engaged in an armed conflict short of war. This is not a civilian disturbance or a demonstration or a riot. It is characterized by live-fire attacks on a significant scale both quantitatively and geographically .... The attacks are carried out by a well armed and organized militia, under the command of the Palestinian political establishment. $^{227}$

In defining the term "armed conflict," the state attorney referred to its definition in modern international law, which defines it, inter alia, as "any situation of a violent dispute (declared or not declared) in which at least one state is

224 Supplementary Notification, ibid at para. 11. In terms of the "A" zones strikes, the state attorney speaks of territories under full civilian and military control of the Palestinian Authority. See Israeli-Palestinian Interim Agreement on the West Bank and the Gaza Strip (Washington, D.C., 28 September 1995) (reproduced in 36 I.L.M. 557).

225 Supplementary Notification, ibid. [emphasis added]. For the definition of "substantial acts of combat," the state attorney relied upon the judgment of the Supreme Court in Kanaan $v$. Commander of IDF forces in Judea and Samaria, H.C.J. 2461/01 [unpublished].

226 Supplementary Notification, ibid. at para. 13.

227 Position Paper (29 December 2000) at para. 286 [emphasis added]. involved."228 However, such a dispute does not conform precisely to "a state of 'war' in the classic sense," and is therefore termed "[a]n Armed Conflict Short of War."229 In the state attorney's opinion, "this definition accurately reflects the situation in the territories, for despite the fact that the State is currently in an 'armed conflict' in the framew ork of which substantial acts of combat are occurring in the territories, these acts of combat do not constitute 'war' in the classic sense." ${ }^{, 230}$ Here, the state attorney directed attention "specifically to the fact that, as is well known, the Palestinian Authority does not have the status of a state, and the dispute is being conducted against terrorist organizations, and not against a regular army.... [Consequently,] the events in the territories should be subject to the Law of Armed Conflict, which substantively speaking is identical to the Law of War."231

The state attorney offered three possible classifications for this armed conflict that may affect the applicable rules of the law of war. ${ }^{232}$ One possibility is to regard it as "a kind of an international armed conflict," the logic being that "conceptually the conflict between Israel and the Palestinians is similar in its characteristics to an international armed conflict, since the conflict extends beyond the borders of the state. Yet, considering the fact that the drafters of the Geneva Convention and the Hague Regulations did not foresee the existence of an international armed conflict that takes place between a sovereign state and a super-national organization, the laws applicable under these conventions, should be applied on the present conflict with the necessary

228 Supplementary Notification, supra note 219 at para. 28.

229 Ibid. at para. 29. For the definition of this term, the state attorney referred to Michael N. Schmitt, "State Sponsored Assassination in International and Domestic Law" (1992) 17 Yale Journal of International Law 609 at 642-43.

230 Supplementary Notification, ibid. at para. 30. The judge advocate general, Major General Menachem Finkelstein, wrote that the judge advocate unit coined the term "Armed Conflict Short of War" as reflecting the present situation. Menachem Finkelstein, "Legal Issues in Times of Conflict" (2002) 16 Israel Defence Forces Law Review 15 at 26-27.

231 Supplementary Notification, ibid.

232 Public Committee Against Torture, supra note 218 (Supplements to the State Attorney's Office Summations,, submitted on 21 January 2004) (Hebrew) ch. E at para. 68 [Supplements to Summations] [translated by author]. 
qualifications resulting from the fighting against non-state organizations." ${ }^{\text {233 }}$

Another possibility is "to regard the conflict between a state and a terror organization as a noninternational armed conflict," since it takes place with an organization that is not a state. In offering this classification the state relied on "a novel approach . . . in the literature . . that determines the term 'non-international armed conflict' as covering all conflicts that do not fall within the framework of the definition of 'international armed conflict." ${ }^{234}$

The problem with these classifications is that under established rules, the term "international armed conflict" relates to a conflict between states, while the term "non-international armed conflict" relates to "a conflict between the authorities of a state and insurgents or rebels in its territory." 235 Therefore, the state attorney offered an alternative way to apply the rules of the Law of War to the conflict between Israel and the terrorist organizations. The way is to regard it as "a different category of an armed conflict that is not covered by a specific convention. ${ }^{236} \mathrm{He}$ submitted that a novel category of "armed conflicts between states and against terrorist organizations" is developing in international law, even though no "exclusive set of laws and specific applicable rules" were set for this category. This novel approach favors "the development of a unique Law of War" that will suit itself to the reality under which the terror organizations "do not subject themselves to any Law of War."237

When discussing internal Israeli law, the state attorney relied upon section 1 of Basic Law: The Army (1976) under which "the very name of the army expresses the concept that its role is to defend the state and its residents. ${ }^{" 238}$ The source of the power for the army's actions is found in section 18 of the Law and Administration Ordinance 1948 as well as section 40 of the Basic

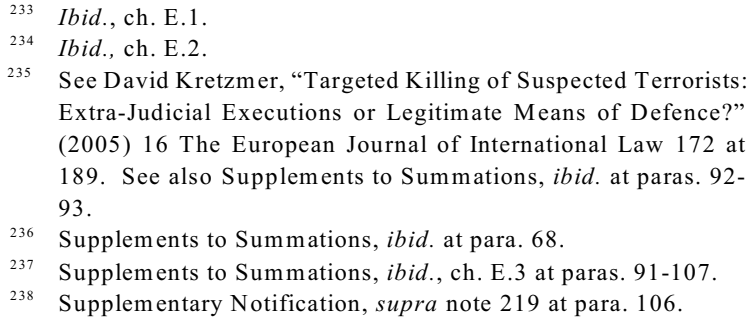

235 See David Kretzmer, "Targeted Killing of Suspected Terrorists: Extra-Judicial Executions or Legitimate Means of Defence?" (2005) 16 The European Journal of International Law 172 at 189. See also Supplements to Summations, ibid. at paras. 92 93.

236 Supplements to Summations, ibid. at para. 68

237 Supplements to Summations, ibid., ch. E.3 at paras. 91-107.

238 Supplementary Notification, supra note 219 at para. 106.

Law: The Government (2001). The state attorney stated that "[f]rom this section it emerges that the State possesses natural and inherent authority to protect itself. In this framework the government has the power to start a war against the enemies of the State (in the classic sense of the term). Likewise, the army is authorized to perform the military actions necessary for the purpose of protecting the State and in order to guarantee the security of its residents, even in the absence of a state of war, in the classic sense of the term."239 The state attorney further explained:

These powers flow from the basic obligation of the State, as any other state in the world, to protect its existence and peace, and the well-being of its citizens. On the basis of this duty the State, and its agents, have the natural right of self defence in the broad sense of the term, against the terrorist organizations, which desire to eliminate it and eliminate its residents and who commit terrorist attacks in order to further their goals... .

The Army's power to adopt military actions for the protection of the State and its residents, as specified in these pieces of legislation, leads to the reliance upon the laws of war in customary international law, which constitute the best source of interpretation in this context, for they deal with military actions taken in order to protect public and state security. ${ }^{240}$

Thus, in this case, the state attorney was arguing that the norms fixed in customary international law were incorporated into Israeli law, given that they do not conflict with the laws of the state. In fact, in a different case that dealt with the events of the Intifada, the Supreme Court ruled as follows: "Israel is currently engaged in a hard battle against raging terrorism.... [T]his battle does not take place in a normative vacuum; it is conducted in accordance with the rules of international law, which establish rules for the

\footnotetext{
239 Ibid. at para. 107.

240 Ibid. at paras. 103, 92.
} 
prosecution of war." ${ }^{241}$ Continuing its argument, the state attorney added:

[E]ven in the absence of a statutory source for the IDF's adoption of military actions under sections 18 of the Law and Administration Ordinance and 40(b) of Basic Law: The Government, (and alternatively, section 32 of the Basic Law: The Government which establishes the government's residual power), the rules of customary international law applicable in this case (i.e. customary laws of war), have independent status, as a source that empowers the IDF to perform such actions, and establishes their classification, by virtue of the principle of "direct incorporation" of the customary international law in the law of our country. ${ }^{242}$

Finally, summarizing the issue, the state attorney stated:

Regardless of whether we refer to customary international law by "direct reference," under the basic principles of our system, or as "a method for giving substance to the statutory Israeli law" which establishes the principles for the regulation of the issue, the result would be that combat actions of the State are governed by Israeli Law - which means, the provisions of "law of war" in customary international law in addition to the applicable provisions of Israeli Law. ${ }^{243}$

In their response, the petitioners rejected the state attorney's claim that "the legality of targeted killings should be determined in accordance with the laws of war" and the claim that "a person who is directly involved in acts of hostility is a legitimate target [for attack]," irrespective of whether he is a "legal combatant" or whether he is

241 Almandi, supra note 217, cited to online: The State of Israel, Judicial Authority <http://62.90.71.124/eng/verdict/ fram esetSrch.html> .

242 Supplementary Notification, supra note 219 at para. 106.

243 Ibid. at para. 107 defined as an "illegal combatant."244 In their summations, the petitioners reiterated their claim that the battle against terrorism should be conducted in accordance with the criminal law and not the law of war. First, the petitioners claimed that the entire area of the West Bank, including areas controlled by the Palestinian Authority are considered, in terms of international law, as territories under "belligerent occupation." 245 The petitioners base their determination on the claim that according to article 42 of the rules annexed to the Hague Convention on Laws and Customs of War on Land, ${ }^{246}$ the status of belligerent occupation is not a function of permanent military presence but rather of the ability to control the territory in the sense that the conquering force is able to exercise its authority in the area. ${ }^{247}$ According to the petitioners:

There can be no doubt that the conduct of the State of Israel and its army in the Territories answers the definition of "effective control." They have direct control of the entry and exit to these territories, into which no person enters and from which no one departs without our consent. They carry out detentions in the Palestinian cities and villages. The IDF has the ability to control over water and food supply, the flow of medicines

244 Public Committee Against Torture, supra note 218 (Petititoners' Response to the Supplementary Notification of the State Attorney's Office at para. 18) (Hebrew) [Petitioners' Response] [translated by author]. See also Ben-Naftali \& Michaeli, supra note 223 at 253. They submit that "[e]ssentially, three fields of international law may be relevant to the case at hand [targeted killing]: human rights law, the laws of war and humanitarian law" (at 253). In their view, "any attempt to analyze the issue of targeted killings from the perspective of merely one applicable field of law will provide neither a comprehensive, nor accurate answer to the question of its legality" (at 254).

245 Petitioners' Response, ibid. at para. 36.

246 Hague Convention No. IV, 18 October 1907, 36 Stat. 2277, T.S. No. 403 (reproduced in James Brown Scott, ed., The Hague Conventions and Declarations of 1899 and 1907 (New York: Oxford University Press, 1915) at 100).

247 The petitioners based their statement on Loizidou v. Turkey (1985), 10 Eur. Ct. H.R. (15318/89) (Preliminary Objections at para. 62), online: Worldlii <http://www.worldlii.or g/eu/cases/ECHR/1995/10.html>. See also Dieter Fleck, The Handbook of Humanitarian Law in Armed Conflicts (Oxford: Oxford University Press, 1995) at 243-44; H. Lauterpacht, ed., International Law, 7th ed.: A Treatise, by L. Oppenheim (London: Longmans, 1948) at 435; Von Glahn Gerhard, The Occupation of Enemy Territory: A Commentary on the Law and Practice of Belligerent Occupation (Minneapolis: University of Minnesota Press, 1957) at 28-29; and, Yoram Dinstein, The Law of War, supra note 38 at 209-10. 
and other consumer products, Palestinian imports and export, and in effect there is no governmental power that the IDF does not have, at least in potential. ${ }^{248}$

The petitioners added that " $[\mathrm{t}]$ he fact that the IDF voluntarily divested its (or pursuant to the voluntary directive of the Israeli government), responsibilities in a number of civilian areas does not preclude the classification of their control over the Territories of the Palestinian Authority as one of belligerent occupation." 249 As such, "the laws of belligerent occupation apply to the areas of the Palestinian Authority . . . and Israel is obliged to comply with provisions of humanitarian law which relate to the situation of belligerent occupation." 250

The petitioners accepted the state attorney's determination that "within the occupied territories there are periods of real combat, and that tremendous significance attaches to that fact in the legal classification of the conflict."251 Nonetheless, they denied the claim that "the targets for elimination are combatants within the meaning of that term in international humanitarian law." They further added that " $[\mathrm{t}]$ he petitioners' position is that the status of members of the Palestinian organizations, both those who perform acts against the citizens of Israel and those who do not, is the status attaching to citizens of an occupied territory (and as such they do not have the right to fight)." 252 They claimed:

[F] or political reasons the State's position evades the classification of the conflict under international law. The respondents' determination that the situation in the territories is one of "An Armed Conflict Short of War" is not a legal determination, just as the concept of "illegal combatants" does not exist in international law. If this is an attempt to give a precise factual description of the events to the extent of there being a conflict, which is not conducted between two armies of two states - then while

\footnotetext{
248 Petitioners' Response, supra note 244 at para. 46.

249 Ibid.

$250 \quad$ Ibid. at para. 53.

251 Ibid. at para. 57

252 Ibid.
}

correct, it is legally irrelevant. The reason is that international law does not distinguish between "full-scale war" and "an armed conflict short of war," but only between an "international armed conflict" and an "armed conflict which is not international. "253

The petitioners claimed that this is a critical distinction in international law, since international laws of war apply primarily to international armed conflicts. The petitioners rejected Israel's request to apply "the laws of combat - Jus in bello - as a result of the armed conflict in the territories (and not the principles of policing, for example, as accepted with respect to internal disturbances, or regarding the relations between the occupying force and the citizens under occupation)." 254 According to the petitioners, it is incumbent upon the state to indicate the specific category of "armed conflict" in order to "be exempted" from the restrictions applicable to policing and "regular" law enforcement, and to enter the category of the world of conflicts with its attendant rights and obligations. The petitioners further argued:

The fact that the State claims the existence of an 'armed conflict' is of no avail to the State. For there can also be a nondescript "armed conflict" between the police and crime organizations, which are subject to the principles of policing and law enforcement, and not to international laws of war. The State was unable to indicate any legal distinctions between "armed conflict," and "armed conflict short of war," even though the petitioners agreed with the position [of the State] that over the years, the laws of war have in effect become the wars of "international armed conflict," which apply to a wider range of international conflicts than in the past. ${ }^{255}$

Ultimately, according to the petitioners, Israel finds itself in a trap due to its refusal "to accept that the conflict flows from a battle for freedom of a nation battling for its right to self determination, which, in their opinion, can be asserted under the

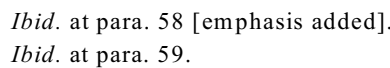


provisions of section 1(4) of the First Protocol of 8 June 1977 to the Geneva Convention of 12 August 1949."256

The petitioners' view was that the Court's questions could be answered only by one of the following two options:

Either that the struggle in Israel and in the Territories is an international armed conflict between the IDF and Palestinian combatants, who are fighting against the Israeli Occupation, in the framework of their struggle for self-determination, and who also commit war crimes (to the extent that it concerns intentional harming of the civilian population).

Or that the struggle in Israel and in the Territories is a struggle of citizens, who do not belong to any legitimate combatant force, and who are inter alia committing murderous and despicable acts the aim of which is injuring the innocent.

Should we choose the first option, then those Palestinians who are fighting have the right to fight and they are therefore entitled to the status of prisoners of war in the event of their capture. On the other hand, if the second option is the correct one, then IDF's handling of breaches of law should be the police-oriented treatment geared to law enforcement. ${ }^{257}$

The petitioners recognized that unlike the previous Palestinian uprising, the current Intifada was characterized by the existence of "regular and recognized combatant forces." 258 However, according to the petitioners, the existence of these forces does not override the "civil dimension of the violence" raging in the territories.

256 Ibid. at paras. $62-63$

257 Ibid. at para. 69 [emphasis added].

258 Ibid. at para. 71 . The petitioners were referring to the fact that while in the 1987 the Territories were under full Israeli occupation, the present uprising involves regular forces of the Palestinian Authority.
The petitioners further argued:

[A] distinction must be made between two phenomena: The international armed conflict, which is legal and legitimate in terms of the international law (without addressing the question of the legality of the beginning of the conflict, which belongs to another area of Jus in Bellum); and, the phenomenon of suicide attacks and other attacks against citizens, and attacks on soldiers which are all undertaken by Palestinian citizens, which are seriously criminal both according to municipal law and according to the international law. ${ }^{259}$

In light of this distinction, the petitioners gave the following answer to the Court's question regarding the rules of international law applicable to the situation:

These are the branches of international law which apply to the ongoing dispute in the occupied territories:

Jus in bello - to the extent that it relates to the international armed conflict being conducted in the conquered territories between the IDF and the Palestinian combatants. Special importance attaches to the distinction between combatants and non-combatants, which is the metaprinciple in this area.

Laws of belligerent occupation - and the provisions relating to questions of the enforcement of public order and the law, to the extent that it relates to the struggle against citizens

International humanitarian law - as the legal umbrella and interpretative tool for the laws of armed conflict, and directly and mandatory as regards the relations between the IDF and the occupied civilian population. ${ }^{260}$

\footnotetext{
259 Ibid. at para. 79 [emphasis added].

260 Ibid. at para. 92
} 
Even with respect to the applicable rules of internal Israeli law, the petitioners distinguished between "the set of laws that applies to the armed conflict to the extent that it exists and at the time of combat, and the set of laws that applies to the relations between the IDF and the Palestinian civilian population." Activities undertaken in the framework of the armed conflict are qualified by the "limitation of criminal liability of soldiers performing actions permitted to them under the laws of war." This is not the case regarding "those elements of IDF activity in the Occupied Territories which relate to the IDF confrontation and relations with the civilian population, even if some of them commit crimes and even if there are individuals engaging in despicable attacks against the innocent." "On that level," the petitioners claimed that "the limitations prescribed in the criminal law continue to apply, together with all the other Israeli laws that determine what is permitted and forbidden to the law enforcement forces in the Occupied Territories."261

In arguing that Israeli criminal law applied to the actions of the IDF with respect to civilians in the Occupied Territories, the petitioners recognized that additional elements of internal Israeli law also applied. The petitioners clarified this position as follows:

Apart from the prohibitions prescribed in the laws of war against harm to the civilian population, which constitute customary international law that applies to any armed conflict, and apart from the prohibitions established by the laws of belligerent occupation, that also delineate the permitted and the forbidden actions in the relations of the occupying force with the occupied civilians - the Israeli criminal law, as well as the Israeli administrative law, constitute an independent source for the restriction of IDF actions, in a manner independent of international law. ${ }^{262}$

Thus, according to the petitioners, the result is:

[T]he Israeli criminal law and the Israeli administrative law apply to all actions of the IDF in the territories, while with respect to frameworks that can be regarded as an international armed conflict, the IDF soldiers enjoy the protection provided to them under the law of war . . . except that the reality of occupation and as such, anything stated regarding the relations of the IDF soldier with the civilian population, relations which are not governed by the laws of war, but rather by the laws of belligerent occupation. These laws do not offer any special criminal defence to the soldiers acting in contravention thereof, beyond the defence given to the exercise of force in order to enforce the law, and maintain order (which cannot be regarded as combat). ${ }^{263}$

The issue raised in this case is of vital importance. Traditional international law seems to fall short of coping with the new phenomenon of transnational terrorism. The preventive steps taken by Israel - as well as by the United States ${ }^{264}$ - in fighting this reality have had mixed reactions in

262 Ibid. at para. 98. In this claim, the petitioners relied on the ruling of the Supreme Court that "[i]n fulfilling his duty the Israeli position-holder carries the duty of conducting himself in accordance with additional criteria, which are dictated by virtue of his being an Israeli authority, regardless of the location of the action. .. . [T] he position-holder will not generally comply with his duty if only behaving in accordance with the norms of international law, because as an Israeli Authority, more is requested of him, namely, that even in the realm of the military government he conduct him self in accordance with the rules laid down for proper and fair governance." Basil Abu Aita v. The Regional Commander of Judea and Samaria, H.C.J. 69/81, 37 P.D. 197 at 231 (Hebrew) [translated by author] [emphasis added]. For an English translation, see online: The Knesset, The State of Israel, Judicial Authority $<$ http://62.90.71.124/eng/ verdict/framesetSrch.html $>$.

263 Petitioners' Response, ibid. at paras. 99-100.

264 For the American policy of preventive self-defence, see U.S. National Security Council, The National Security Strategy of the United States of America (Government Printing Office, September 2002) at 13-16, online: The White House $<$ http://www.whitehouse.gov/nsc/nss.pdf $>$. 
legal literature. ${ }^{265}$ The judgment of the Supreme Court of Israel on this issue has therefore been long-awaited, as it might set a precedent in Israeli law, and arguably also in international law. However, on 16 February 2005, the Court decided to postpone the proceedings in the case. ${ }^{266}$ The Court did so in view of the developments that took place between Israel and the Palestinian Authority. On 8 February 2005 both parties reached what is known as "the Sharm el-Sheikh understandings." According to them, "all Palestinians will stop all acts of violence against all Israelis everywhere and [in a parallel manner], Israel will cease all its military activity against all Palestinians anywhere." 267 The Court decided to halt the proceedings "in view of the prime minister's statement." ${ }^{268}$ The Court decided it will resume the proceedings if it is informed of "a change in the situation." 269

\section{EPILOGUE}

The statutory regulation of powers of war under Israeli law differs from extant arrangements in other democracies. To start with, unlike the

265 For a sample of legal articles dealing with this issue, see Daniel Statman, "Targeted Killing" (2004) 5 Theoretical Inquiries in Law 179; George Nolte, "Preventive Use of Force and Preventive Killings: Moves into a Different Legal Order" (2004) 5 Theoretical Inquiries in Law 11; Michael L. Gross, "Fighting by Other Means in the Mideast: a Critical Analysis of Israel's Assassination Policy" (2003) 51 Political Studies 1; Jonathan I. Charney, "The Use of Force against Terrorism and International Law" (2001) 95 American Journal of International Law 835; Thomas M. Franck, "Terrorism and the Right of Self-Defense" (2001) ) 95 American Journal of International Law 839; Steven R. David, "Israel's Policy of Targeted Killing" (2003) 17 Journal of Ethics \& International Affairs 111; Schmitt, supra note 229; Kretzmer, supra note 235; BenNaftali \& Michaeli, supra note 223.

266 Public Committee Against Torture, supra note 218, Court decision from 16 Febuary 2005 (Hebrew), online: State of Israel, Judicial Authority <http://elyon2.court.gov.il/files/02/ 690/007/A27/02007690.A27.pdf >

267 Statement by Prime Minister Ariel Sharon at the Sharm elSheikh Summit (Hebrew), online: Prime Minister's Official Site $<$ http://www.pmo.gov.il/PMOEng/Communication/PMSpeak s/speech080205.htm $>$ [translated by author].

268 Public Committee Against Torture, Court decision from 16 Febuary 2005, supra note 266 . It should be emphasized that the Palestinian Authority failed in putting an end to the acts of violence against Israelis. Thus, in briefs submitted on 23 February in the case of Alian v. Prime Minister, H.C.J. 4825/04 (Hebrew), the state attorney declared: "In front of Israel stands a line of terror organizations that operate mainly from territories under the control of the Palestinian Authority. The Palestinian Authority collapsed and did not prevent the acts of terror." [translated by author].

269 Public Committee Against Torture, ibid.
Japanese constitution, ${ }^{270}$ Israeli law does not prohibit war. Even so, the Basic Laws dealing with the army and military action indicate that there is a restriction upon the conduct of war and military actions not intended for defence purposes. As opposed to other democratic systems, the power to start a war does not vest in the prime minister as head of the executive. Nor is the power to declare war and to initiate military action divided between the executive branch and Parliament.

In Israel, the range of powers for the conduct of war, from the actual decision to go to war until the adoption of military actions in order to protect the state and the public security, are conferred exclusively on the government. The Knesset's involvement in the area is marginal, and the government's decision does not require Knesset approval. From this perspective, even though it is not explicit in the law, the government is in fact the supreme commander of the army.

We further saw that there are substantive issues that are not statutorily regulated, and that the legislation itself is far from being unequivocal. We noted that many of the arrangements in this area are governed by customs that are not totally clear, and several of the expressed arrangements require further clarification and improvement. A great deal also depends on the character traits of the central persons involved, specifically the prime minister, the minister of defence, and the chief of staff. We also encountered the judicial supervision over the executive branch, including supervision over its combat actions, which are without precedent in other legal systems.

Another prominent feature in all stages of the discussion is the fact that municipal law has adjusted itself to the changes that took place in the arena of international law. Hence, even though Israeli law currently includes provisions regarding the declaration of war, these provisions have no practical application. This is the result of the prohibition imposed by international law on the initiation of wars. This factor lead to the proposals to change the classification of the laws of war from "Law of War" to "Law of Armed Conflict."

\footnotetext{
270 See John O. Haley, “Waging War: Japan's Constitutional Constraints" (2005) 14:2 Constitutional Forum constitutionnel 18 .
} 
This classification conforms with the relations that actually exist between the combatant parties, without attempting to label them with disputed tags regarding the classification of the conflict. It also allows the application of the laws of war, including their humanitarian aspect, without having to address the heart and cause of the dispute. The classification and its background lead to the novel proposal of recognition of the legal institution of Armed Conflict Short of War and the attempt to subject it to the traditional law of war.

Finally, it is suggested that the long-standing duration of the state of war in Israel, which has continued since the State of Israel was established, has made Israeli law a fascinating stage for the examination of legal arrangements concerning the beginning of a war, matters relating to military actions, and the relations between the civilian and military authorities in these matters.

\section{Asher Maoz}

Associate Professor

Faculty of Law, Tel Aviv University

Editor-in-Chief of "Law, Society and Culture"

maoza@post.tau.ac.il 


\section{APPENDIX}

The following are two alternative proposals for the amendment of Basic Law: The Army, that were submitted to the Constitution, Law, and Justice Committee of the Knesset. ${ }^{271}$

\section{The Army}

Essence

1 The Defence Army of Israel is the army of the State.

Subordination to civil authority

2 (a) The Army is subject to the authority of the Government.

(b) The Minister in charge of the Army on behalf of the Government is the Minister of Defence [Version B: unless the Prime Minister himself decides to be the Minister in charge for a particular matter or for a particular period]. ${ }^{272}$

\section{Chief of General Staff}

3 (a) The Supreme level of command in the Army is the Chief of the General Staff.

(b) The Chief of the General Staff is subject to the authority of the Government.

(c) The Chief of the General Staff will be appointed by the Government, upon the recommendation of the Minister of Defence [Version B: which has been approved by the Prime Minister].

Duty to serve and recruitment

4 The duty of service in the Army and recruitment for the Army shall prescribed by law, or by virtue of explicit author-

271 Nun, supra note 170 at 176 [translation by author]

272 Regarding version 'B:' The version ensures that there is no parallel subordination to the Government and to the Prime Minister, and Prime Minister's ability to override the provision of the Minister of Defence is for cases in which the Prime Minister decided to be the Minister in charge on behalf of the Government for a certain matter or for a certain period.

\section{ization in such law $^{273}$}

Instructions and commands in the Army

5 The power to issue binding instructions and commands in the Army shall be prescribed by law or by virtue of explicit authorization such law

Establishment of another armed force

6 Version A: A sovereign authority shall not establish an armed force external to the Defence Army of Israel except by law or by virtue of explicit authorization therein. ${ }^{274}$

Version B: No armed force ${ }^{275}$ shall be established or maintained external to the Defence Army of Israel except by law or by virtue of explicit authorization therein However, the Government/ Knesset may permit an international armed force, or of a foreign state to be stationed in Israel [for a particular purpose or a particular period]. ${ }^{276}$

\section{Basic Law: The Government (War and Military Actions)}

War and military operations

40 (a) The State shall not begin a war except pursuant to a Government decision that shall be approved in advance [Version B: or as soon as possible

273 The concluding parts of sections 4 and 5 use the same wording as appears in the restrictive override clauses of the Basic Laws concerning human rights

274 If the provision is directed to the State Authorities, there is no need to make an exception for foreign forces staying with permission.

275 Instead of the existing expression "armed force" which creates non-clarity regarding the use of arms by various security forces. The phrase "military power" is clearer in terms of the intention to prohibit armed militias.

276 Version $\mathrm{B}$ in the concluding section is intended to clarify that the purpose of the section is not to compel enactment of legislation for any "stationing" of armed forces of a foreign state or international foreign forces, whose stay in Israel was approved by the competent authorities (even though the status of U.S. forces was prescribed by law). See Status of U.S. Personnel Agreement Law, S.H. 5763 / 1992-1993 at 62. The stationing of foreign forces in Israel today requires government approval. If a decision is made in the section regarding Approval of Agreements and Conventions (in the chapter dealing with the Knesset) to also make this matter subject to the Knesset approval, then this section will be adjusted accordingly. 
after being issued $]^{277}$ by the Knesset or one of the committees accordingly empowered by the Knesset, as prescribed by law.

(b) An extensive military operation or a military operation that is liable to lead to war [or: to an extensive armed confrontation] or that may have an extensive impact on State security or on the foreign relations of the State, requires the approval of the Government or a part thereof as prescribed by law; ${ }^{278}$ notification of an operation as stated shall be given to the Knesset or to a committee accordingly empowered by the Knesset [or a part thereof [Version $C$ : in advance or...] as soon as possible, as prescribed by law. ${ }^{279}$ [Version D: The Government approval. . . and consultation with the committee accordingly empowered or a part thereof, as prescribed by law $]^{280}[\mathbf{V}$ ersion $\mathbf{E}$ : The Government approval ... and approval [in advance or] as soon as possible... of the Knesset committee....

(c) Nothing in this section shall prevent urgent military operations, which are required for the purpose of the

277 Version B indicates that the war can be begun even before the Knesset's approval, even though this is not the only interpretation. The matter should be resolved and the constitutional version should be clarified accordingly. It will be necessary to make provisions in the Government Law, or in the Knesset Law regarding the manner of informing the Knesset and the Knesset procedure (committee, plenum).

278 According to this version, the specification regarding the time at which the prime minister and the defence minister or additional ministers give their approval, the time for bringing it to the cabinet and to the government plenum - will all be determined in the Government Law. In a law it is possible to draw precise distinctions and determine the minimal number of ministers required to adopt decisions in particular matters. For example, the Government Law may determine that if the prime minister considers it justified under the circumstances - the operation can be approved by the prime minister, the minister of defence or additional ministers, as specified by the prime minister.

279 The Knesset Law, or the Government Law, will specify when, how and in what particular forum notification will be given, and when and how the notification will be transmitted to the plenum; the entire matter will also be dependent on the timing of the notification in relation to the operation.

280 Here it is clear that the consultation precedes the operation, and there is therefore a need to determine the limited forum and the form of consultation. defence of the State and public security.

\section{Version A: \\ Basic Law: Israel Defense Force}

Israel Defense Forces

1 (a) Israel Defence Forces are the army of the State.

(b) Israel Defence Forces shall comprise land forces, navy and air forces, and other forces as determined by the Government with the approval of the Knesset Foreign Affairs and Security Committee.

Subordination to civil authority

2 (a) The army is subject to the authority of the Government.

(b) The minister in charge of the Army on behalf of the Government is the Minister of Defence.

(c) The army is subject to the authority of the Government and subordinate to the Minister of Defence; For as long as the Government has passed no decision on the matter - the army will operate according to the instructions of the Minister of Defence.

War and military operations

3 (a) The State shall not start a war or military operation except pursuant to a Government decision; the conduct of war shall be in accordance with Government decisions.

(b) Nothing in this section shall prevent military actions required for the purpose of defending the State and public security.

(c) Notification of a Government decision to start a war or a military operation under this subsection, shall be transmitted to the Knesset Foreign Affairs and Security Committee as soon as possible; the Prime Minister shall also transmit the notification to the Knesset plenum as soon as possible; notifications of Government decisions regarding the conduct of the war shall be submitted to the Knesset Foreign Affairs and Security 
Committee from time to time.

(d) Notification of military activities as stated in subsection (b) shall be given to the Knesset Foreign Affairs and Security Committee as soon as possible.

Prohibition on Engagement in political matters

4 (a) The Army and those in military service shall not engage in political matters or in matters of publiccontroversial nature except subject to limitations prescribed by law.

(b) Nothing in this section shall prevent the Chief of the General Staff or a person empowered by him from presenting his professional view of matters relating to the army and State security, provided that it is done in the manner determined by the Government or the Minister of Defence.

\section{Chief of Staff}

5 (a) The supreme command level in the army is the Chief of the General Staff.

(b) The Chief of the General Staff is subject to the authority of the Government and subordinate to the Minister of Defence; in tactical, operational and other similar matters, the Chief of the General Staff is exclusively subject to the authority of the Government.

(c) The Chief of the General Staff shall be appointed by the Government upon recommendation of the Minister of Defence.

Army service

6 (a) Recruitment for the Army shall be as prescribed by Law.

(b) Army service and the rights of those engaged in army service who have completed their service, shall be as prescribed by Law.

Instructions and commands in the Army

7 The power to issue binding instructions and commands in the Army shall be prescribed by Law.
Powers of the Army

8 (a) The Army is empowered to perform all of the military actions required in order to defend the State, subject to the instructions of the civil authority.

(b) The Army shall not be utilized for non-military purposes, whether inside the State of Israel or outside thereof, except as prescribed by law, and to a degree that does not exceed what is absolutely necessary.

Purpose of army service

9 Those serving in army shall not be utilized for non-military purposes, whether inside the State of Israel or outside thereof, except as prescribed by law, and to a degree that does not exceed what is absolutely necessary.

Other armed forces

10 No armed force other than the Israel Defence Forces shall be established or maintained except under Law.

Law not to be affected by emergency regulations

11 Notwithstanding the provisions of any law, this Basic law cannot be varied, or temporarily suspended, or made subject to conditions by emergency regulations.

Entrenchment of Basic Law

12 This Law shall not be changed except by a majority of members of the Knesset; the majority required under this subsection shall be required for decisions of the Knesset plenum in the first, second and third reading; for the purpose of this section, "change" - whether explicit or implied. 


\section{Version B:}

In this proposal, the provisions have been divided between constitutional provisions, to be included the Basic Law, and secondary provisions to be included in an ordinary statute.

\section{Basic Law: Israel Defense Force}

Israel Defense Forces

1 Israel Defense Forces are the army of the State.

Subordination to civil authority

2 (a) The army is subject to the authority of the Government.

(b) The minister in charge of the Army on behalf of the Government is the Minister of Defence.

(c) The army is subject to the authority of the Government and subordinate to the Minister of Defence; For as long as the Government has passed no decision on the matter - the army will operate according to the instructions of the Minister of Defence.

Prohibition on Engagement in political matters

3 (a) The Army and those in military service shall not engage in political matters or in matters of publiccontroversial nature except subject to limitations prescribed by law.

(b) Nothing in this section shall prevent the Chief of the General Staff or a person empowered by him from presenting his professional view of matters relating to the army and State security, provided that it is done in the manner determined by the Government or the Minister of Defence.

\section{Chief of Staff}

4 (a) The supreme command level in the army is the Chief of the General Staff.

(b) The Chief of the General Staff is subject to the authority of the Government and subordinate to the Minister of Defense; in tactical, operational and other similar matters, the Chief of the General Staff is exclusively subject to the authority of the Government.

(c) The Chief of the General Staff shall be appointed by the Government upon recommendation of the Minister of Defence.

Army service

5 (a) Recruitment for the Army shall be as prescribed by Law.

(b) Army service and the rights of those engaged in army service who have completed their service, shall be as prescribed by Law.

Instructions and commands in the Army

6 The power to issue binding instructions and commands in the Army shall be prescribed by Law.

Powers of the Army and purpose of army service

7 (a) The powers of the Army and the purpose of army service shall be as prescribed by law.

Other armed forces

8 No armed force other than the Israel Defence Forces shall be established or maintained except under Law.

Law not to be affected by emergency regulations

9 Notwithstanding the provisions of any law, this Basic law cannot be varied, or temporarily suspended, or made subject to conditions by emergency regulations.

Entrenchment of Basic Law

10 This Law shall not be changed except by a majority of members of the Knesset; the majority required under this subsection shall be required for decisions of the Knesset plenum in the first, second and third reading; for the purpose of this section, "change" - whether explicit or implied. 
Amendment of Basic Law: The Government

11 In Basic Law: The Government, instead of section 40 there shall come:

(a) The State shall not start a war or military operation except pursuant to a Government decision; the conduct of war shall be in accordance with Government decisions.

(b) Nothing in this section shall prevent military actions required for the purpose of defending the State and public security.

(c) Notification of a Government decision to start a war or a military operation under this subsection, shall be transmitted to the Knesset Foreign Affairs and Security Committee as soon as possible; the Prime Minister shall also transmit the notification to the Knesset plenum as soon as possible; notifications of Government decisions regarding the conduct of the war shall be submitted to the Knesset Foreign Affairs and Security Committee from time to time.

(d) Notification of military activities as stated in subsection (b) shall be given to the Knesset Foreign Affairs and Security Committee as soon as possible.

\section{Israel Defence Forces Law, 2002}

Purpose

1 (a) The purpose of this Law is to prescribe details and arrangements in all matters concerning the nature, roles and powers of Israel Defence Forces, as they are determined in the Basic Law: The Army.

Composition of Israel Defence Forces

2 Israel Defence Forces shall comprise land forces, navy and air forces, and other forces as determined by the Government with the approval of the Knesset Foreign Affairs and Security Committee.

Engagement in political matters

3 (a) Officers of the rank of Brigadier General and upwards and military attaches, as well as rank holders or other position holders serving in the Army (hereinafter - "Licensees for Political Matters") determined by the Minister of Defence with the approval of the Knesset Foreign Affairs and Security Commission, are entitled to engage in political matters and in public controversial matters, to a degree not extending what is necessitated by the nature of the matter.

(b) Licensees for Political Matters shall not be permitted to express themselves in public in relation to these matters, except with the approval of the Minister of Defence or a person empowered by him; nothing in the provisions of this section shall derogate from the power of the Minister of Defence to prescribe additional restrictions on expressions of those serving in the Army.

(c) Engagement in controversial public matters shall not be permitted unless they are political matters, and exclusively by Licensees for Political Matters, and subject to the provisions of this section.

Rights of those in Army service

4 (a) Those serving in Army service shall be entitled to wages and benefits as prescribed from time to time in Army regulations, subject to the provisions of this Law and its regulations.

(b) Those serving in Army service whose salary is not sufficient to provide for their needs and the needs of their dependents, shall be entitled to assistance from the Israel Defence Forces, as determined from time to time in the Army regulations, subject to the provisions of this Law and its regulations.

Rights of persons completing army service

3 (a) Persons completing regular army service shall be entitled to benefits and additional rights as prescribed by law; these benefits shall not - as such 
- provide cause for granting additional benefits or rights to others.

(b) Persons completing permanent army service, after a period which shall be determined, shall be entitled, in addition to the foregoing, to a pension to be paid to them throughout their lives, in accordance with rules prescribed by law.

Powers of Army and purposes of army service

5 (a) The Army is empowered to perform all of the military actions required in order to defend the State, subject to the instructions of the civil authority.

(b) The Army shall not be utilized for non-military purposes, whether inside the State of Israel or outside thereof, except for national security purposes or for purposes necessary for preserving the foreign relations of the State, and to a degree that does not exceed what is absolutely necessary.

Purposes of Army service

6 (a) Persons serving in the Army shall be empowered to perform any act for which the Army is empowered.

(b) Those serving in army service shall not be utilized for non-military purposes, whether in the framework of the Army or externally to it, except for national security purposes and to a degree that does not exceed what is absolutely necessary.

(c) With respect to this section and section 5, it is presumed that where an objective can be attained other than by utilization of the Army or those serving in the Army, with an additional budgetary allocation, then the use of the Army or those serving in the Army for its attainment is in excess of what is absolutely necessary.

Regulations

7 The Minister of Defence is charged with the implementation of this Law and is authorized to make regulations for any matter relating to its implementation. 